\title{
Estratigrafia dos Derrames de Basaltos da Formação Serra Geral (Ribeirão Preto - SP) Baseada na Geologia Física, Petrografia e Geoquímica
}

\author{
Stratigraphy of the Basalt Flows of the Formação Serra Geral (Ribeirão Preto - SP) \\ Based on Physical Geology, Petrography and Geochemistry
}

\author{
Amélia João Fernandes' (ameliajf@igeologico.sp.gov.br), Carlos Henrique Maldaner² (cmaldaner@gmail.com), \\ José Maria Azevedo Sobrinho' (zemaria@igeologico.sp.gov.br), \\ Márcia Maria Nogueira Pressinotti (marciapressinotti@hotmail.com), Ingo Wahnfried² (iwahn@yahoo.com) \\ 'Instituto Geológico - SMASP \\ Av. Miguel Stéfano 3.900, CEP 04301-903, São Paulo, SP, BR \\ ${ }^{2}$ Instituto de Geociências - USP, São Paulo, SP, BR
}

Recebido em 08 de dezembro de 2009; aceito em 14 de abril de 2010

\section{RESUMO}

A motivação que levou ao estudo da geologia física e química dos basaltos de Ribeirão Preto foi investigar a existência de recarga do Sistema Aquífero Guarani (SAG) através dos basaltos do Aquífero Serra Geral (ASG), objetivo do projeto abreviadamente denominado FRATASG. Além de métodos hidrogeológicos, a pesquisa demandou uma investigação geológica de detalhe, a qual é essencial para a elaboração de modelos conceituais de circulação de água subterrânea em aquíferos complexos, caso dos basaltos do ASG. Assim, o estudo contemplou trabalhos de campo para descrição dos aspectos macroscópicos e das relações entre os basaltos e os arenitos subjacentes, coleta de amostras e análises petrográficas e químicas. Também foram utilizados dados de perfis litológicos de cinco poços construídos no projeto FRATASG, fundamentais para o estabelecimento da estratigrafia em subsuperfície. O estudo concluiu que, na área de Bonfim Paulista, ocorrem quatro derrames de basaltos, denominados B1, B2, B3 e B4, do mais antigo para o mais jovem. A ocorrência de B4 é muito restrita, pois foi erodido em grande parte. B1 e B2 apresentam espessuras de, em média, 45 e 55 m, respectivamente. Todos os quatro basaltos são do tipo sheet like lobes e devem ter sido colocados pelo mecanismo de inflação. B1 apresenta espessa crosta vesicular superior e, assim como em B2, pode apresentar mais de um nível vesicular no topo. Colunas de resfriamento foram observadas em B2 e B3, sendo mais espetaculares em B3 devido à presença de uma camada colunada inferior (B3-C) e uma sobreposta com entablamento (B3-E). B3 é o derrame mais espesso (75 a $100 \mathrm{~m})$ e contém brechas hidráulicas distribuídas em bolsões, posicionados na camada B3-C, ou ao longo de fraturas sub-horizontais que até hoje permitem circulação de fluidos (água subterrânea). B3 apresenta composição química homogênea e é perfeitamente distinguível de $\mathrm{B} 1$ e $\mathrm{B} 2$ com relação a vários óxidos $\left(\mathrm{Al}_{2} \mathrm{O}_{3}, \mathrm{P}_{2} \mathrm{O}_{5}, \mathrm{Fe}_{2} \mathrm{O}_{3}, \mathrm{TiO}_{2}\right.$ e $\left.\mathrm{MgO}\right)$ e elementos traço (Ni, $\left.\mathrm{Zn}, \mathrm{Cu}, \mathrm{Y}\right)$. A distinção entre $\mathrm{B} 1$ e $\mathrm{B} 2$ restringe-se aos óxidos $\mathrm{P}_{2} \mathrm{O}_{5}$ e $\mathrm{TiO}_{2}$ e aos elementos $\mathrm{Cu}, \mathrm{Zn}, \mathrm{Y}$ e Ni.

Palavras-chave: Formação Serra Geral; Basaltos; Estratigrafia; Petrografia; Geoquímica.

\section{ABSTRACT}

The study of the physical geology and geochemistry of the basalts of Ribeirão Preto was part of a hydrogeological research that aimed at investigating the recharge of the Guarani Aquifer System (SAG) through the basalts of the Serra Geral Aquifer (ASG), a project shortly named FRATASG. In addition to hydrogeological methods, the research demanded a detailed geological investigation, which is essential for the elaboration of conceptual models of groundwater circulation in complex aquifers, as is the case of the fractured basalts of the ASG. Thus, the study encompassed field work for the description of the macroscopic aspects and relationships among the basalts and the underlying sandstones, as well as, rock sampling and petrographic and chemical analysis. Furthermore, the use of lithologic logs of five wells drilled in FRATASG 
project was essential for the establishment of the subsurface basalt stratigraphy. The study concluded that, in Bonfim Paulista region, there are four basalt floods, namely B1, B2, B3 and B4. The B4 occurrence is very restricted as it was largely eroded. B1 and B2 average thicknesses are 45 and $60 \mathrm{~m}$, respectively. All four basalts are of sheet-like lobe types and were probably emplaced by inflation, B1 being the one that presents more evidence in that respect. B1 presents a thick vesicular top and, as well as B2, can show more than one vesicular layer at the top. Columnar joints were observed in B2 and B3 and are more remarkable in B3, where a lower colonnade tier (B3-C) is overlain by an entablature layer (B3-E). B3 is the thickest flow (75 to $105 \mathrm{~m})$ and contains irregular and roughly round patches of hydraulic breccia in B3-C or along sub-horizontal fractures that allow the circulation of fluids (groundwater at the present). The chemical composition of $\mathrm{B} 3$ is homogeneous and very different from $\mathrm{B} 1$ and $\mathrm{B} 2$ with regard to several oxides $\left(\mathrm{Al}_{2} \mathrm{O}_{3}, \mathrm{P}_{2} \mathrm{O}_{5}, \mathrm{Fe}_{2} \mathrm{O}_{3}\right.$, $\mathrm{TiO}_{2}$ e $\left.\mathrm{MgO}\right)$ and trace elements $(\mathrm{Ni}, \mathrm{Zn}, \mathrm{Cu}, \mathrm{Y})$. $\mathrm{B} 1$ is very different from $\mathrm{B} 2$ with regard to $\mathrm{P}_{2} \mathrm{O}_{5}, \mathrm{TiO}_{2}, \mathrm{Cu}, \mathrm{Zn}, \mathrm{Y}$ and Ni.

Keywords: Serra Geral Formation; Basalts; Stratigraphy; Petrography; Geochemistry.

\section{INTRODUÇÃO}

O Instituto Geológico, em parceria com a USP - Universidade de São Paulo, USGS - Serviço Geológico dos Estados Unidos, UQAC - Universidade de Quebec em Chicoutimi, e com colaboração do IPT - Instituto de Pesquisas Tecnológicas, ON - Observatório Nacional e COC - Universidades COC, desenvolveu estudo geológico e hidrogeológico de detalhe em área localizada no distrito de Bonfim Paulista, município de Ribeirão Preto, com o intuito de responder à seguinte questão: existe recarga do Sistema Aquífero Guarani (SAG) através dos basaltos do Aquífero Serra Geral (ASG)?

A motivação deste estudo é o fato do SAG, o mais importante e estratégico manancial de água potável do Brasil, estar sendo ameaçado, em termos de qualidade e quantidade, devido à instalação de grandes centros urbanos em áreas constituídas de basalto e próximas ao afloramento do SAG. Alguns indícios hidrogeoquímicos como concentrações elevadas de nitrato e cloreto, detectadas em poços do SAG, na área urbana de Ribeirão Preto, levantam a possibilidade desta contaminação chegar ao SAG através de fraturas transmissivas verticais do ASG. Assim, o projeto “A Formação Serra Geral como conexão hidráulica entre a superfície e o Sistema Aquifero Guarani: análise estrutural e ensaios in situ - FRATASG" realizou investigações geológicas e hidrogeológicas de detalhe para contribuir para o entendimento do fluxo vertical através dos basaltos.

Os métodos utilizados no projeto envolveram desde mapeamento geológico de detalhe e estudo das estruturas tectônicas rúpteis até ensaios hidráulicos e estudos hidroquímicos e isotópicos. Neste artigo são apresentados os resultados referentes à geologia e geoquímica dos basaltos que ocorrem no distrito de Bonfim Paulista, município de Ribeirão Preto. Ressalta-se que a estratigrafia estabelecida com base em afloramentos e nos perfis litológicos de poços, construídos e amostrados no projeto FRATASG, foi claramente confirmada pela composição química dos basaltos.

\section{MATERIAIS E MÉTODOS}

\section{Pesquisa bibliográfica}

Com relação à Formação Serra Geral, a pesquisa bibliográfica enfocou os seguintes temas: contextualização geral da Formação na Bacia do Paraná em termos de constituição, quimismo e idade; geologia física dos derrames de basalto (zoneamento, espessura e extensão lateral, geometria das fraturas de esfriamento etc.); morfologia dos terrenos basálticos; processos de colocação das lavas basálticas; interação com sedimentos intertrappe.

Apenas atualmente alguns trabalhos têm se dedicado ao estudo da geologia física da Formação Serra Geral, como, por exemplo, o de Waichel et al. (2006). A literatura mais antiga é derivada, em grande parte, dos estudos realizados para a construção de barragens nos Estados de São Paulo e Paraná, cujo enfoque foi geotécnico.

\section{Elaboração de seções geológicas}

Foram elaboradas quatro seções regionais na área de Ribeirão Preto e quatro seções locais em Bonfim Paulista (Figura 1). Neste artigo são apresentadas uma das seções regionais e duas das locais. As regionais basearam-se nos seguintes dados: perfis litológicos de poços disponíveis em cadastro do projeto SIA-Guarani (SMA/São Paulo e STMUGV/Baviera, 2004), complementado no projeto FRATASG; base topográfica em escala 1:50.000 do IBGE; e mapa geológico de Sinelli et al. (1973). As seções locais e o mapa geológico, restrito à área de Bonfim Paulista, foram elaborados com base na descrição de afloramentos, de perfis de poços do cadastro, bem como de poços construídos no projeto FRATASG, e em cartas topográficas 1:10.000 do IGc (cartas Fazenda São Thomaz, Bonfim Paulista, Ribeirão Preto VI e Ribeirão Preto VII). As cotas originais dos poços foram mantidas nas seções, fazendo com que seu topo ficasse acima ou abaixo da topografia representada, já que 
parte deles se encontra um pouco afastada do traçado das seções e, consequentemente, em cotas distintas.

\section{Elaboração de mapa de contorno estrutural da base dos basaltos}

Mapa de contorno estrutural da base dos basaltos foi elaborado com base na descrição dos perfis geológicos de 166 poços que, entre os 398 poços constantes do cadastro, continham esta informação. Tabela com as coordenadas dos poços e cota de base do basalto foi utilizada na interpolação pelo método de krigagem ordinária. Esta permite ajustar os parâmetros de entrada a partir de variogramas experimentais, construídos com o programa Geovisual (de autoria de Jorge Kazuo e Marcelo Rocha, IGc/USP). Os variogramas foram feitos nas duas direções com maior anisotropia na distribuição dos valores (N25E e N65W).

\section{Trabalhos de campo}

Os levantamentos geológicos de campo consistiram em descrição de 50 afloramentos, sendo que a maioria deles se localiza a leste da área urbana de Bonfim Paulista. Também foi realizado levantamento detalhado de dados estruturais com o objetivo de identificar estruturas de importância para o fluxo de água subterrânea. Os resultados deste levantamento são tratados em Fernandes, Rouleau e Maldaner (em preparação).

\section{Análises petrográficas e químicas}

Das amostras coletadas, 32 foram laminadas e descritas ao microscópio petrográfico Jenapol e 20 foram submetidas a análises químicas pelo método de fluorescência de raio $\mathrm{X}$ em laboratório do Instituto de Geociências da USP (principais óxidos, elementos traço e perda ao fogo). Os elementos maiores foram obtidos a partir de pastilhas fundidas e os elementos traço em pastilhas de pó prensado; tais métodos são descritos em detalhe por Mori et al. (1999).

\section{CONTEXTO GEOLÓGICO: A FORMAÇÃO SERRA GERAL}

No Estado de São Paulo, os basaltos da Formação Serra Geral (Eocretáceo) superpõem-se à Formação Botucatu (Jurássico-Cretáceo). São sobrepostos pelos grupos Bauru e Caiuá (Neocretáceo), conforme descritos em Fernandes e Coimbra (2000) e, nas regiões onde este grupo não ocorre, por sedimentos cenozoicos.

A Formação Botucatu consiste de arenitos quartzosos finos a grossos, bem selecionados e arredondados, com estratificações cruzadas de grande porte, indicando deposição em ambiente eólico desértico (Almeida, 1954). Localmente intercalam-se sedimentos mais finos de ambiente lacustre.

A oeste do rio Mogi-Guaçu, próximo à área de estudo, a Formação Serra Geral é superposta pela Formação Vale do Rio do Peixe, pertencente ao Grupo Bauru e composta por arenitos finos a muito finos intercalados com siltitos ou lamitos arenosos (Fernandes e Coimbra, 2000). Corresponde, em grande parte, à antiga Formação Adamantina, definida por Soares et al. (1980).

Coberturas areno-argilosas relativamente extensas e delgadas (máximo de $10 \mathrm{~m}$ de espessura), sem estruturas sedimentares, depositadas a partir do Terciário, também recobrem diretamente os basaltos, ocorrendo em larga escala na região nordeste do Estado, tanto na região da Depressão Periférica, quanto nas Cuestas Basálticas (Bjornberg, 1965; Soares et al., 1973; Melo, 1995; entre outros). Distinguem-se dos arenitos Bauru por ser frequente a presença de nível basal de acumulação de clastos de quartzo, quartzitos e diversos tipos de concreções limoníticas, e por conterem fragmentos de carvão vegetal dispersos a até $6 \mathrm{~m}$ de profundidade e grande quantidade de magnetita (Sinelli, 1971a; Melo, 1995). Sedimentos aluviais e baixos terraços quaternários, constituídos por areias, areias argilosas e turfeiras também ocorrem na região (Soares et al., 1973).

A sequência de derrames da Formação Serra Geral, como citado em Milani (2004) beira os $2.000 \mathrm{~m}$ no depocentro das lavas, situado na região do Pontal do Paranapanema. No poço de Cuiabá Paulista os basaltos alcançam espessura de $1.700 \mathrm{~m}$ (Almeida, 1986). Esta formação pertence à Província Magmática do Paraná (PMP), que ocorre nas regiões sul e sudeste do Brasil, uma das maiores províncias de basaltos continentais do mundo, cuja colocação precedeu a abertura do Atlântico Sul, com a fase principal de atividade vulcânica entre 133 e $130 \mathrm{Ma}$ (de acordo com síntese de Nardy, Machado, Oliveira, 2008). Esta província constitui-se principalmente de rochas vulcânicas e intrusivas (diques e soleiras) basálticas de natureza toleítica (Cordani e Vandoros, 1967; Melfi, Piccirillo, Nardy, 1988; Marques e Ernesto, 2004).

Nardy et al. (2002) propõem três unidades litoestratigráficas para a Formação Serra Geral, denominadas de Unidade Básica Inferior, Membro Palmas e Membro Chapecó, com base em mapeamento em escala regional. A primeira representa $95 \%$ do volume das rochas vulcânicas da Bacia do Paraná, e a segunda e terceira, $2 \%$ e $0,5 \%$, respectivamente, sendo que ambas sobrepõem-se à Unidade Básica Inferior. No entanto esta estratigrafia não é sustentada na parte norte da província magmática, onde os basaltos de alto Ti são mais jovens que os dacitos Chapecó, como demonstra a coluna de Peate, Hawkesworth e Mantovani (1992) e os trabalhos realizados em Ourinhos, como os de Picirillo et al. (1987) e Janasi et al. (2007). 


\section{Geologia Física}

O zoneamento vertical dos derrames de basalto foi descrito inicialmente por Leinz (1949) e consiste em: 1) base constituída por vidro e basalto com fraturas horizontais; 2) porção central de basalto denso com fraturamento vertical originado por resfriamento; e 3) topo composto por zona de fraturamento horizontal superposta por zona vesicular amidaloidal, que pode estar mineralizada por quartzo, calcita, zeólitas ou fluorita. Posteriormente, inúmeros autores descrevem zoneamento semelhante, como, por exemplo, Sinelli (1971a) na região de Ribeirão Preto.

Leinz (1949) ressalta a morfologia em degraus das regiões constituídas por derrames basálticos onde os patamares sub-horizontais, ou de baixa declividade, correspondem às zonas vesiculares e de fraturas horizontais; nestes a decomposição e a erosão avançam predominantemente na horizontal. As encostas de declividade acentuada correspondem ao basalto denso com fraturas verticais, pois estas facilitariam a queda de blocos segundo essas fraturas, devido ao solapamento por decomposição mais rápida do piso formado por zonas vesiculares. Muitas quedas d'água seriam formadas por este processo. Marques Filho et al. (1981) fazem a mesma associação entre a zonalidade dos basaltos e a morfologia para o relevo acidentado e a morfologia em degraus das áreas basálticas das bacias dos rios Iguaçu e Uruguai.

Em mapeamento da porção sudoeste do Paraná, a MINEROPAR/CPRM (2006) utiliza uma variedade de critérios para a separação faciológica e cartografia geológica de basaltos. Estes critérios incluem aspectos macroscópicos texturais e estruturais, além de litoquímica e relações estratigráficas.

A espessura de cada derrame da Formação Serra Geral é muito variável. O perfil elétrico de Presidente Epitácio, no extremo oeste do Estado de São Paulo, com quase $1.800 \mathrm{~m}$ perfurados em basalto, acusa 32 picos que seriam correlacionáveis a zonas vesiculares, indicando o mesmo número de derrames e uma espessura média individual de $50 \mathrm{~m}$ (Leinz et al., 1966). Nardy et al. (2002) citam estudos paleomagnéticos que demonstrariam uma proporção quase constante de quatro derrames de basalto a cada $100 \mathrm{~m}$, resultando em uma espessura média de $30 \mathrm{~m}$ para cada um. No entanto ocorre grande variação de espessura que vai de menos de 10 a $100 \mathrm{~m}$, como, por exemplo, nas barragens de Água Vermelha (divisa de São Paulo com Minas Gerais) e Itaipu onde são observadas espessuras que variam de 7 a 40 m e 20 a 50 m (Bjornberg e Kutner, 1983), respectivamente, notando-se que espessuras menores que $30 \mathrm{~m}$ também são comuns. A determinação da espessura de cada derrame, além de ser dificultada pelas exposições de rocha descontínuas, pressupõe um entendimento a respeito da de- finição do que é um derrame. Neste sentido, são úteis as definições de alguns termos associados à geometria e colocação do magma indicadas por Self, Keszthelyi e Thordarson (1998), que consistem em:

1. Lobos: o menor pacote coerente de lava. Variam desde a escala centimétrica à quilométrica, dependendo da taxa de extrusão da lava.

2. Derrame (flow): produto de um único extravasamento de lava.

3. Campo de derrames: produto de muitos extravasamentos separados de lava.

4. Derrame simples e composto: formados por um ou vários lobos, respectivamente.

5. Sheet flow: corpo contínuo de lava líquida por toda a largura do derrame. A colocação é contínua e relativamente rápida sobre superfícies planas com mergulhos baixos que favorecem a produção de derrames dominados por sheetlike lobes. Este tipo de lobo prevalece em províncias de flood basalt (lava basáltica extremamente fluida que extravasa na superfície como uma série de erupções horizontais e em rápida sucessão, cobrindo áreas muito vastas; são relacionados a ambientes extensionais e à quebra de continentes).

Os derrames pahoehoe são colocados por inflação, i.e., injeção de lava sob uma crosta solidificada. Self, Keszthelyi e Thordarson (1998) apontam que todos os grandes campos de derrames basálticos terrestres estudados até o presente, incluindo flood basalts, foram colocados como derrames em lençol (sheet) e por inflação. Isto levou os autores a propor que este é o modo padrão de colocação de grandes volumes de lava. Este tipo de colocação seria termicamente eficiente, ou seja, devido ao isolamento térmico dado pela crosta solidificada, a redução de temperatura durante o fluxo seria muito pequena $\left(0,001\right.$ a $\left.0,1^{\circ} \mathrm{C} / \mathrm{km}\right)$; isto possibilitaria o fluxo de lava por longas distâncias (até mais que $1.000 \mathrm{~km}$ ) com a formação de lobos muito extensos e com baixa relação espessura/extensão em área (Self, Keszthelyi, Thordarson, 1998; Self, 2008; Self et al., 2008). Muitos dos derrames do Columbia River Basalt Group são do tipo pahoehoe; a extensão lateral pode atingir $600 \mathrm{~km}$. As feições diagnósticas da colocação do tipo pahoehoe são: superfícies pouco rugosas, onduladas e em corda; distribuição interna de vesículas, cristalinidade e juntas.

Segundo Self, Keszthelyi e Thordarson (1998), a inflação dá-se por fluxo contínuo de lava nova e cheia de bolhas de voláteis para dentro do lobo. Depois da estagnação, e para viscosidades típicas de basalto, as bolhas remanescentes devem subir para a superfície em dias ou semanas, gerando um núcleo denso. No entanto, durante a cristalização desse núcleo, elementos incompatíveis, incluindo vo- 
láteis, concentram-se no residuum, o qual pode ascender como diápiros, por flutuação. O residuum é frequentemente muito silicoso (até riolítico), e apresenta maior cristalinidade que a lava circundante. Quando os diápiros ascendentes atingem a base da crosta superior do derrame, eles se espalham na horizontal, formando lençóis vesiculares sub-horizontais, tipicamente de 1 a $5 \mathrm{~cm}$ de espessura, com limites inferiores planares. Os limites superiores são irregulares e refletem a topografia irregular da base da crosta superior e solidificada do basalto. As zonas vesiculares (ZV) têm várias dezenas de centímetros a muitos metros de espessura e se formam por causa da flutuação de pressão e/ou fluxo durante a inflação. A base da ZV inferior e o topo do lençol vesicular marcam a base da crosta superior quando a inflação terminou.

\section{Geoquímica}

Na região sul da PMP predominam basaltos com menor quantidade de titânio $\left(\mathrm{TiO}_{2} \leq 2 \%\right)$ e elementos incompatíveis, associados a vulcânicas ácidas do tipo Palmas; na parte norte predominam basaltos com maior quantidade de titânio $\left(\mathrm{TiO}_{2} \geq 2 \%\right)$ e elementos incompatíveis, juntamente com ácidas do tipo Chapecó (Picirillo et al., 1988). A grande maioria das soleiras é constituída por rochas básicas com altos teores de Ti. De acordo com a assinatura geoquímica de elementos traço incompatíveis (tais como $\mathrm{Zr}, \mathrm{Nb}, \mathrm{Y}$ ), as efusivas e intrusivas de alto Ti da Formação Serra Geral são subdivisíveis em Paranapanema, Pitanga e Urubici (Peate, Hawkesworth, Mantovani, 1992), com conteúdos cada vez mais elevados de $\mathrm{Ti}$ e $\mathrm{Sr}$, sendo que os derrames do Nordeste do Estado de São Paulo são do tipo Urubici $\left(\mathrm{TiO}_{2}>3,3 \%\right.$ e $\mathrm{Sr}>550$ ppm) (Machado et al., 2005; Machado, Nardy, Oliveira, 2007). Basaltos hipovítreos (50 a 90\% de vidro) de Ribeirão Preto apresentam teores de Ti ainda mais elevados $\left(3,37 \%<=\mathrm{TiO}_{2}<=4,47 \%\right)$ (Nardy et al., 2005). Análises de rochas básicas extrusivas e intrusivas, da região de Piraju e Ourinhos, revelam que a geoquímica pode ser utilizada como ferramenta de correlação estratigráfica (Janasi et al., 2007). Foram observadas variações importantes e progressivas nos conteúdos de $\mathrm{MgO}, \mathrm{TiO} 2$, e $\mathrm{P} 2 \mathrm{O} 5$, de elementos traço incompatíveis como $\mathrm{Zr}$ e Sr, e de razões elementares utilizadas para identificar magmas-tipo (Ti/Y, Zr/Y) (Negri, Janasi, Montanheiro, 2008).

\section{Interação com sedimentos}

De um modo geral, próximo ao contato com a Formação Botucatu, há camadas de arenito, de espessuras variáveis, intercaladas em meio aos derrames de basalto, que são mais frequentes e espessas quanto mais próximas à base da Formação Serra Geral.
De acordo com Jerram et al. (2000) e Scherer (2002), os derrames de lava preservaram completamente a morfologia das dunas, pois estas mostram poucos sinais de modificação ou deformação, inclusive preservando marcas onduladas presentes na superfície das dunas (Jerram e Stollhofen, 2002), indicando um mecanismo passivo de colocação das lavas. As dunas preservadas no paleodeserto cretáceo da Bacia de Huab chegam a $100 \mathrm{~m}$ de altura e cerca de $1 \mathrm{~km}$ de comprimento de onda. Existem dunas maiores, porém não são completamente preservadas (Jerram et al., 2000). Isto indica que, no início do evento magmático, um único derrame poderia ser da ordem de $100 \mathrm{~m}$ de espessura, sendo que os topos das maiores dunas, que ficaram descobertas, sofreram a ação dos ventos e formaram as pequenas dunas que compõem os arenitos encontrados entre os derrames. Supõe-se que as maiores dunas possuam altura de pelo menos $160 \mathrm{~m}$ (Jerram et al., 2000). Os mergulhos dos caimentos dos flancos da duna variam de $15^{\circ}$ a $29^{\circ}$ (Jerram et al., 2000). Dunas preservadas por basaltos foram observadas por Almeida (1954) na Serra de Botucatu em São Paulo, mostrando que os basaltos foram colocados quando o paleodeserto Botucatu ainda era ativo. Isto e a recorrência de deposição de dunas entre os derrames de basaltos da base da Formação Serra Geral são evidências de que esta e a Formação Botucatu foram parcialmente contemporâneas (Assine et al., 2004).

Rochas onde há mistura de sedimento e basalto, nos contatos entre derrames, são comuns e em geral de pequena espessura; são elas os peperitos e as brechas. Frequentemente pensa-se que os peperitos se formam devido à presença de água contida nos sedimentos inconsolidados com os quais o magma basáltico entra em contato. No entanto, exemplos de ambiente árido demonstram que os peperitos podem se formar por outros processos que nem sempre requerem água. Com base nisto, Jerram e Stollhofen (2002) propõem que o termo peperito seja descritivo e se relacione a um material que se formou pela interação entre magma juvenil e sedimento, com ou sem a presença de água. Este último aspecto deve ser investigado para cada caso. Brechas ou pseudopeperitos (no sentido de Jerram e Stollhofen, 2002) formam-se pela deposição de areia sobre crostas de basaltos, promovendo uma mistura dos fragmentos da superfície de topo do basalto com a areia.

\section{RESULTADOS}

\section{Geologia da região de Ribeirão Preto}

Na região de Ribeirão Preto ocorrem as formações Piramboia, Botucatu e Serra Geral, além de formações superficiais e aluviões mapeados na escala 1:50.000 por Sinelli et al. (1973). Seções geológicas regionais, das quais 
uma é incluída na Figura 1, mostram que a espessura total de basalto na região varia de 10 a $160 \mathrm{~m}$, com valores mais frequentes de 70 a $110 \mathrm{~m}$. Os perfis dos poços dispostos nas seções mostram variações. por vezes abruptas, das cotas de contato entre a base da Formação Serra Geral e o arenito Botucatu (Figura 1), que muitas vezes têm sido interpretadas como desnivelamentos verticais produzidos por falhas (Sinelli, 1971b). No entanto, tais variações das cotas de contato são compatíveis com a morfologia de dunas, que foram preservadas pelos derrames de basaltos, devido ao mecanismo passivo de colocação das lavas, a exemplo do que é descrito no Estado do Rio Grande do

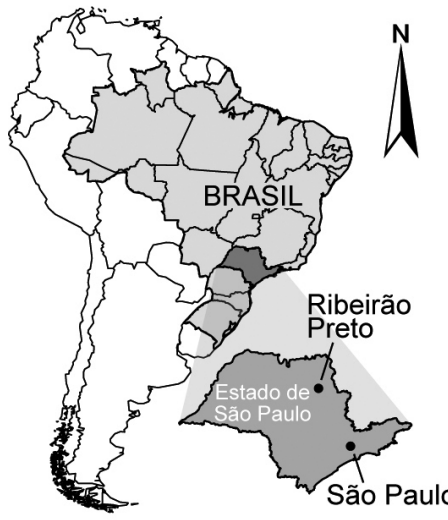

\section{Legenda}

- Afloramentos

- Poços tubulares

- Estradas

- Drenagem

$\square$ Área Urbana

$\square$ Aluvião Quaternário
$\square$ Formações Superficiais
$\square$ Formação Serra Geral
Formação Botucatu
Formação Piramboia
Formação Corumbataí

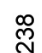
Perfil geológico do poço

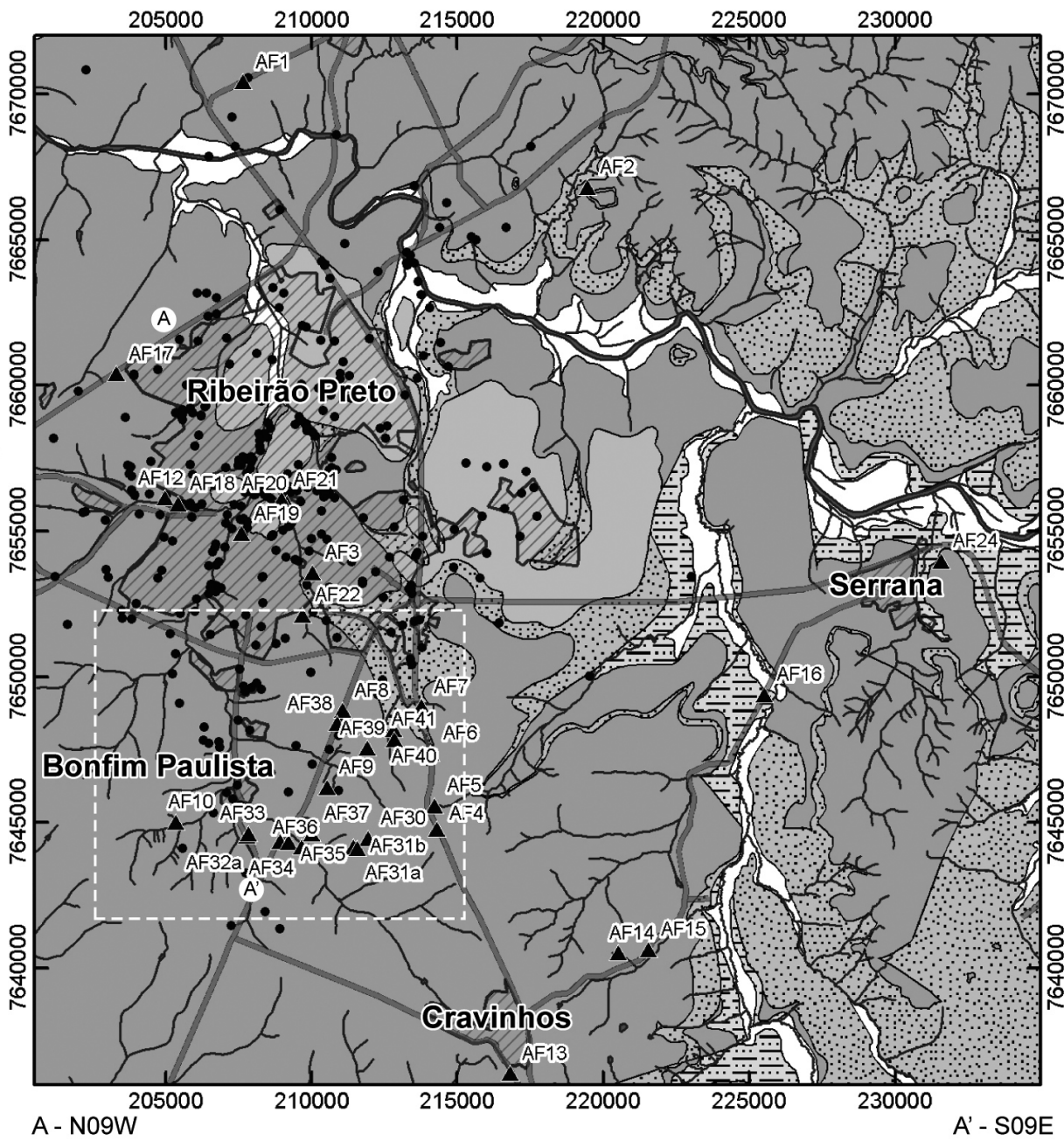

; Contato geológico inferido

Escala do mapa

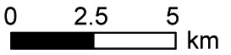

Escala horizontal da seção $0 \quad 1 \quad 2 \mathrm{~km}$

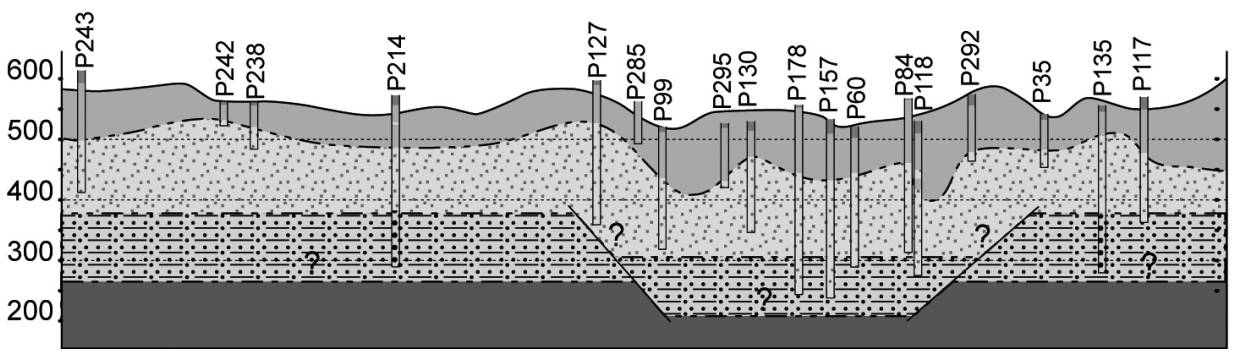

Figura 1. Mapa de localização da área de estudo apresentando poços, todos os afloramentos descritos no projeto FRATASG, e a área selecionada para estudo de detalhe (retângulo tracejado). A geologia foi compilada de Sinelli et al. (1973). A seção $\mathrm{AA}^{\prime}$ foi construída com base nos dados de poços e do mapa geológico. 
Sul por Scherer (2002), e na Bacia de Huab, no noroeste da Namíbia, por Jerram et al. (1999, 2000) e Jerram e Stollhofen (2002). Tomando como exemplo a seção geológica da Figura 1, a superfície de contato dos arenitos da Formação Botucatu com os basaltos apresenta ondulações com comprimento de onda de cerca de $2 \mathrm{~km}$ e amplitude de 50 a $100 \mathrm{~m}$. Além disto, as zonas de cisalhamento e pequenas falhas, observadas na região de Ribeirão Preto, apresentam mergulhos elevados e estrias sub-horizontais, ou de mergulhos baixos, indicando que os deslocamentos tectônicos existentes são predominantemente horizontais, o que caracteriza regime tectônico transcorrente. Desta forma, os dados estruturais também indicam que deslocamentos verticais importantes são menos prováveis.

As cotas mais baixas de contato basalto/arenito coincidem com a região urbana de Ribeirão Preto, como indicado pelo mapa de contorno estrutural do topo da Formação Serra Geral (Figura 2). Segundo Massoli (2007), dados de poços mostram que, nessa mesma região, o contato entre as formações Botucatu e Piramboia também é mais profundo. $\mathrm{O}$ autor considera que tais desnivelamentos verticais são de origem tectônica. Tal hipótese ainda deve ser mais investigada.

As direções de maior anisotropia, identificadas no mapa de contorno estrutural (Figura 2), correspondem a N25E e N65W. A discussão deste dado é aprofundada em Fernandes, Rouleau e Maldaner (em preparação), onde os dados estruturais são apresentados.

\section{Estratigrafia e descrição dos basaltos de Bonfim Paulista}

A estratigrafia dos derrames foi caracterizada, com maior segurança, na área de Bonfim Paulista onde foram identificados quatro derrames de basaltos que receberam, da base para o topo, a seguinte nomenclatura: B1, B2, B3 e B4. Na estrada de Cravinhos para Serrana e nesta última também foram descritos afloramentos de B1, B2 e B3, localizados na Figura 1. Os basaltos contêm vesículas, amídalas e geodos abundantes na sua porção superior e menos abundantes junto aos contatos basais. Estes níveis são denominados de B-VA. O mapa geológico esquemático e a coluna estratigráfica destes derrames são exibidos nas Figuras 3 e 4 . As informações dos poços do cadastro disponível foram úteis principalmente para traçar o contato entre basalto e arenito e também para inferir o número de derrames que ocorrem em áreas com poucos dados de afloramentos, como na porção norte do mapa. Os contatos entre os vários derrames, representados no mapa geológico (Figura 3), foram inferidos a partir dos afloramentos e das quebras negativas de relevo (a exemplo da morfologia em degraus, descrita por Leinz,1949), as quais, em geral, coincidem com o B-VA do topo de cada derrame. A continuidade lateral dos derrames chega, na área de Bonfim Paulista, por exemplo, a pelo menos $11 \mathrm{~km}$, para o B3. A extrapolação desta estratigrafia, para a região circunvizinha a Bonfim Paulista, encontra dificuldades devido às variações das cotas dos contatos. No entanto, os basaltos descritos na pedreira de Serrana (AF24, AF = afloramento), separados entre si por camada pouco espessa de arenito, são correlacionáveis a B1 e B2 (B1 assenta-se diretamente sobre os arenitos Botucatu). Os afloramentos que ocorrem próximo a Cravinhos são correlacionáveis a B3-E (AF14 em cota aproximada de $680 \mathrm{~m}$ - apresenta entablamento, descrito mais adiante), e ao contato B1-VA e B2 (AF15 em cota aproximada de $640 \mathrm{~m}$ - apresenta brechas e arenito entre B1-VA e B2). Assim, a extensão lateral mínima destes derrames na região estudada é de cerca de $30 \mathrm{~km}$.

Com base nas características observadas para os basaltos de Ribeirão Preto, considera-se que eles devam ser do tipo sheet-like lobes colocados sob o mecanismo de inflação, sendo esperado que as suas extensões laterais sejam muito grandes, a exemplo do que ocorre em outras províncias basálticas, como a Columbia River Basalt Group. Isto se contrapõe a outros trabalhos, como o de Marques e Ernesto (2004), onde se afirma, com base na magnetoestratigrafia, que a extensão lateral dos derrames não passa de poucos quilômetros. Derrames pouco espessos de basaltos, e com provável extensão lateral também pequena, são frequentes na porção sul da província, como pode ser depreendido das descrições de Waichel et al. (2006), mas não é o caso da região de Ribeirão Preto.

As características mais marcantes de cada derrame estão sintetizadas na Tabela 1.

\section{Basalto 1 - B1}

O derrame B1 situa-se na base da pilha vulcânica, repousando diretamente sobre os arenitos Botucatu, os quais afloram na porção NE da região mapeada (Figura 3); B1 foi observado em superfície somente no AF7, em Bonfim Paulista, e AF24, em Serrana (Figuras 1 e 3). A posição destes contatos e os dados disponíveis da área de afloramento dos arenitos da Formação Botucatu sugerem que a espessura média de B1 esteja em torno de $45 \mathrm{~m}$. No entanto, os dados dos poços construídos (Figura 5) mostram que a espessura de B1 pode variar de 13 a $50 \mathrm{~m}$.

O basalto denso do B1 é maciço, fanerítico e de granulação fina. Ao microscópio observa-se textura intersertal e microporfirítica, estrutura maciça, e granulação fina (Tabela 2). O nível B1-VA (nível vesicular-amidaloidal de B1) da porção superior contém vesículas, amídalas verdes (clorofeíta/celadonita) e abundantes geodos, centimétricos a decimétricos, alongados na horizontal, preenchidos 


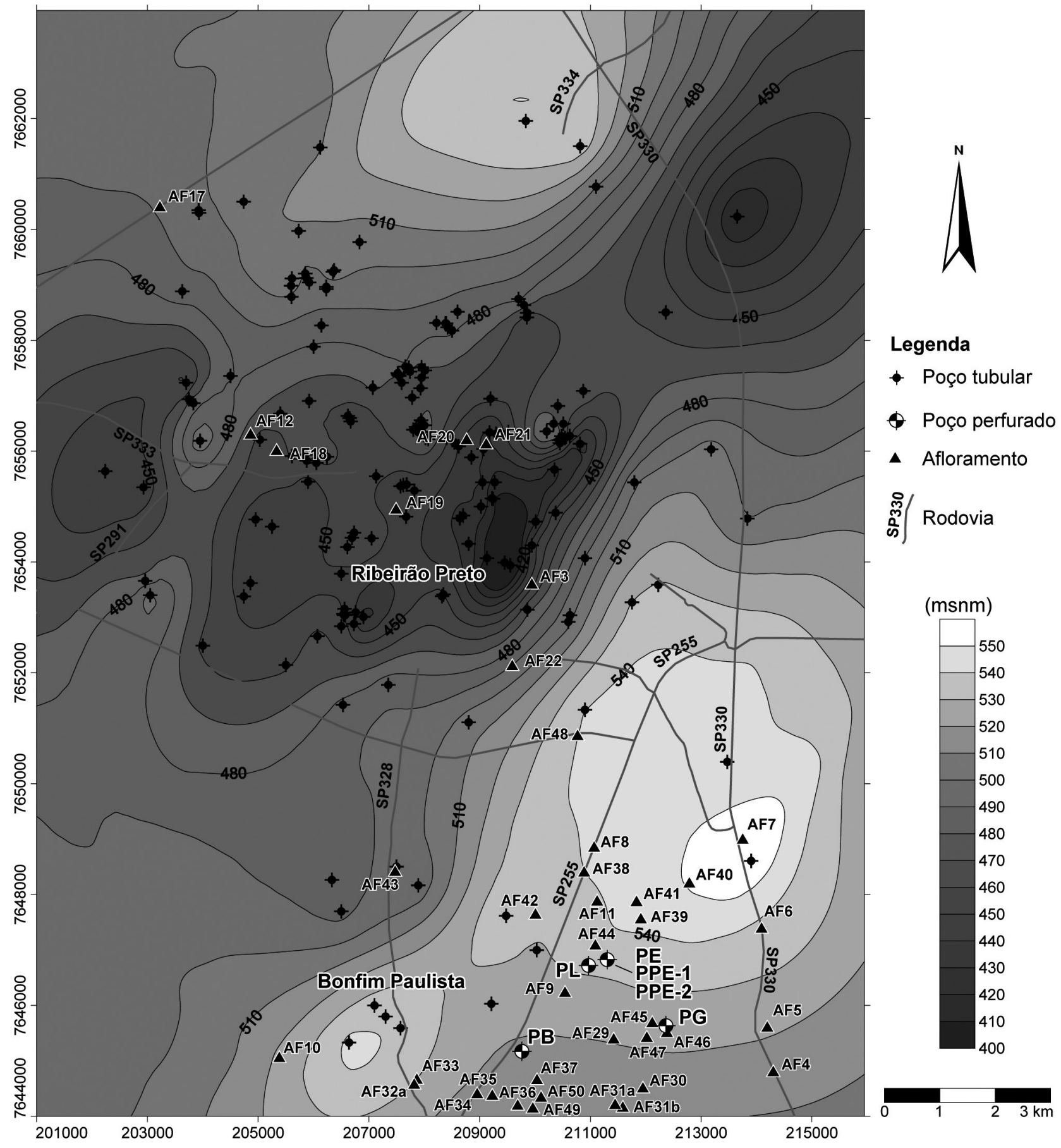

Figura 2. Mapa de contorno estrutural da superfície de topo dos basaltos na região de Ribeirão Preto (SP) contendo localização de poços, afloramentos descritos no projeto FRATASG, e principais rodovias. 

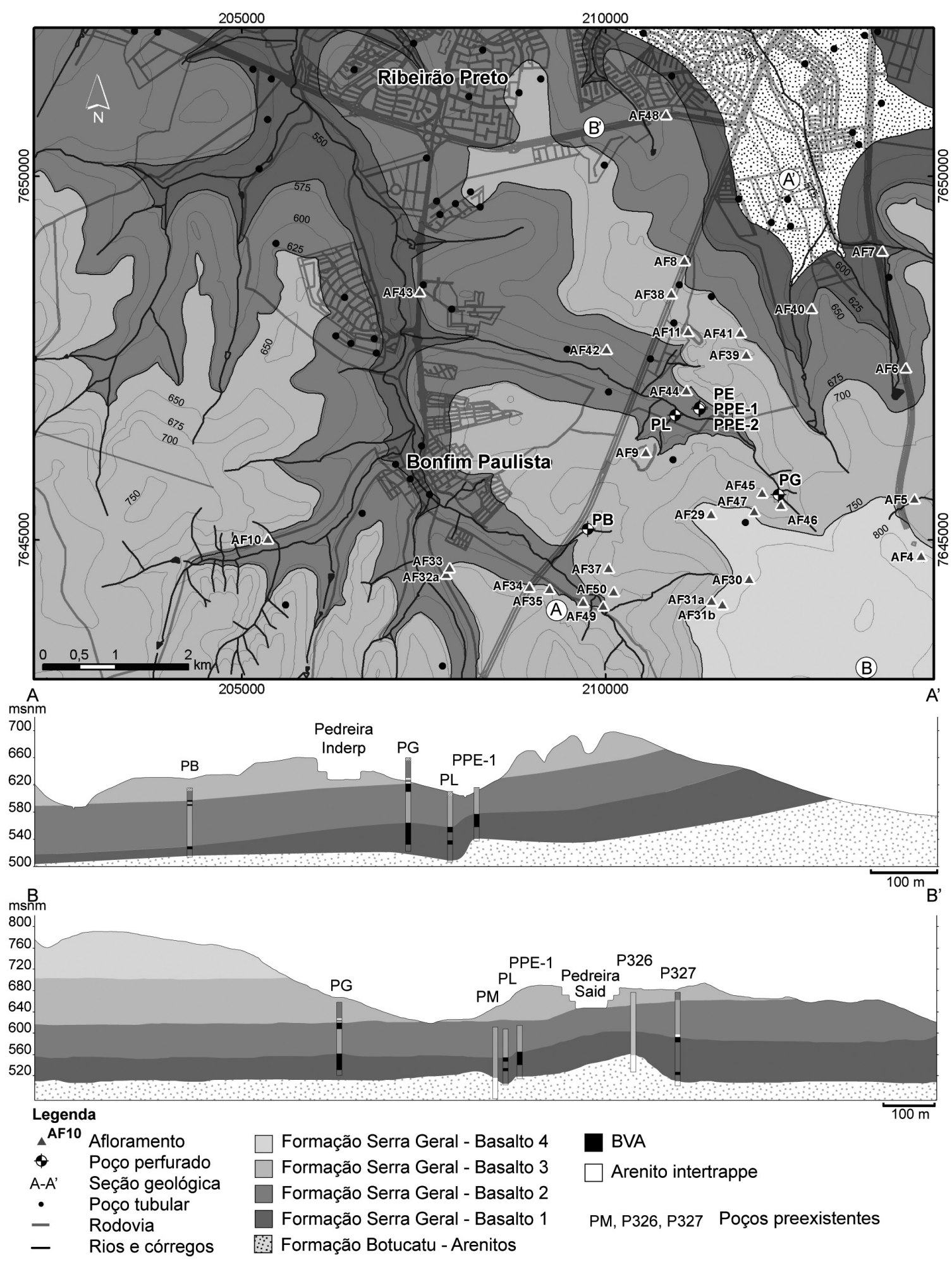

Figura 3. Mapa geológico da área de Bonfim Paulista, mostrando localização de poços preexistentes, de poços perfurados no projeto FRATASG, de afloramentos e das seções geológicas de detalhe. 


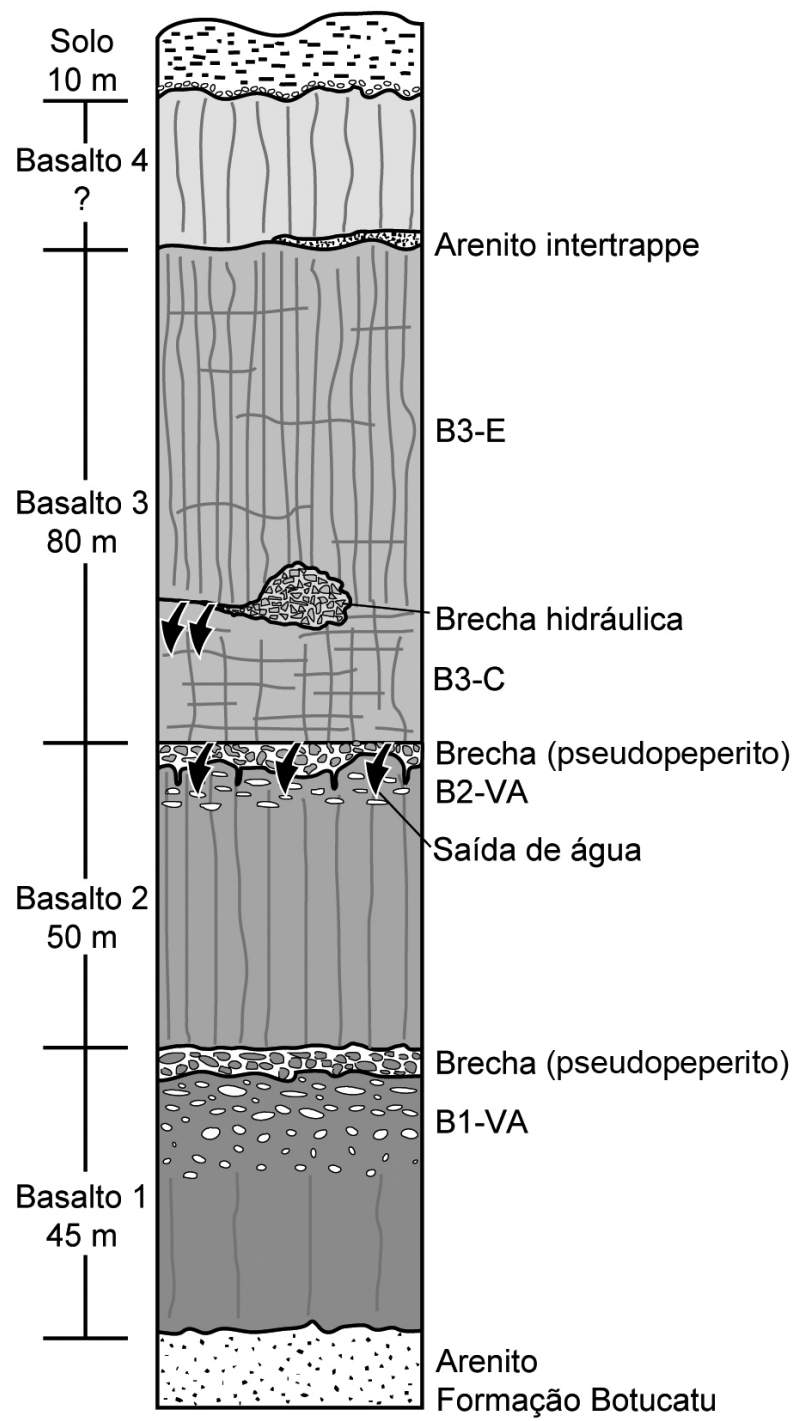

Figura 4. Coluna estratigráfica esquemática dos basaltos mapeados na região de Bonfim Paulista. Brechas ou pseudopeperitos (no sentido de Jerram e Stollhofen, 2002) formam-se pela deposição de areia sobre derrames, promovendo uma mistura dos fragmentos da superfície de topo do basalto com a areia.

principalmente por quartzo, calcita, zeólitas e calcedônia/ágata (AF24, próximo a Serrana). B1 apresenta várias feições, semelhantes às descritas por Self, Keszthelyi e Thordarson (1998), que indicam que sua colocação se deu pelo mecanismo de inflação, tais como: mais de uma zona vesicular na porção superior do derrame (poços PPE1 e PL, Figura 5); zona vesicular muito espessa (Poço PG) com pelo menos $32 \mathrm{~m}$ (Figura 5); vesículas e

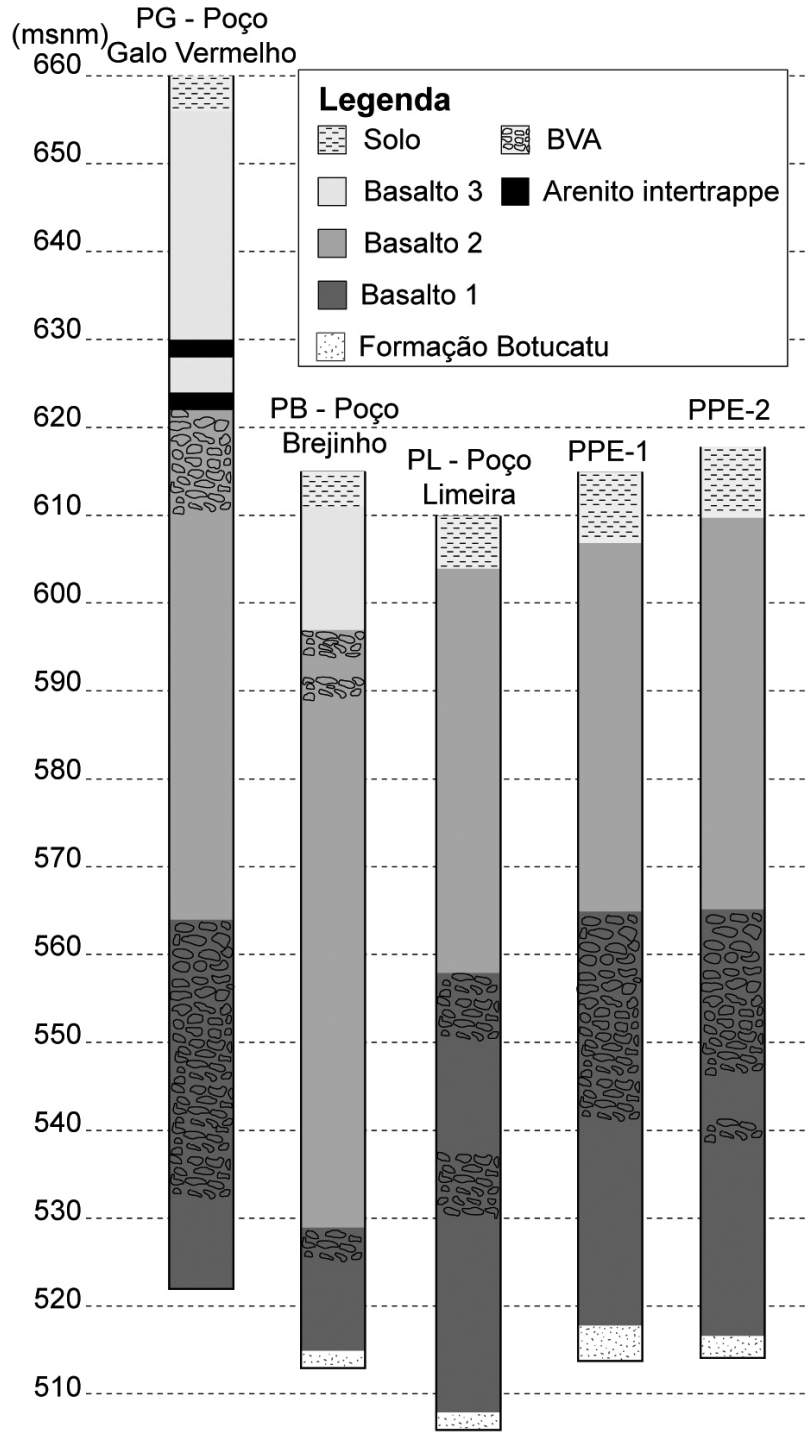

Figura 5. Perfis litológicos dos poços perfurados (Galo Vermelho-PG, Brejinho-PB, Limeira-PL, PPE 1 e PPE2).

geodos tipicamente alongados na horizontal, com base inferior planar e topos irregulares, mostrando a presença de crosta superior solidificada que limita a ascensão das vesículas; veios, de espessura milimétrica, de maior cristalinidade, encontrados no basalto denso, que correspondem aos líquidos residuais (residuum) que se formam durante a cristalização do núcleo denso de basalto; e porções, com limites bem definidos, mais ricas em vesículas e amídalas 


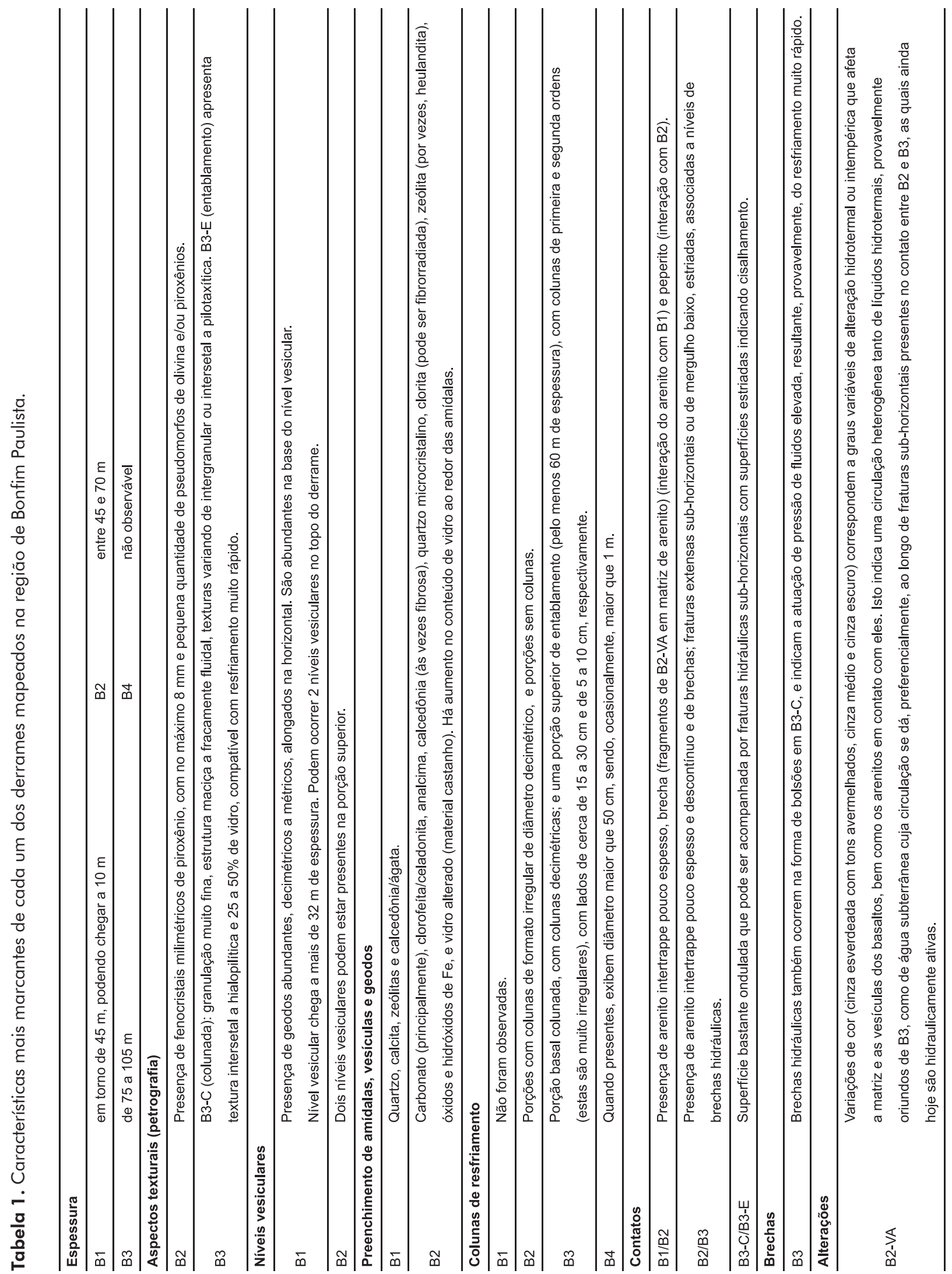




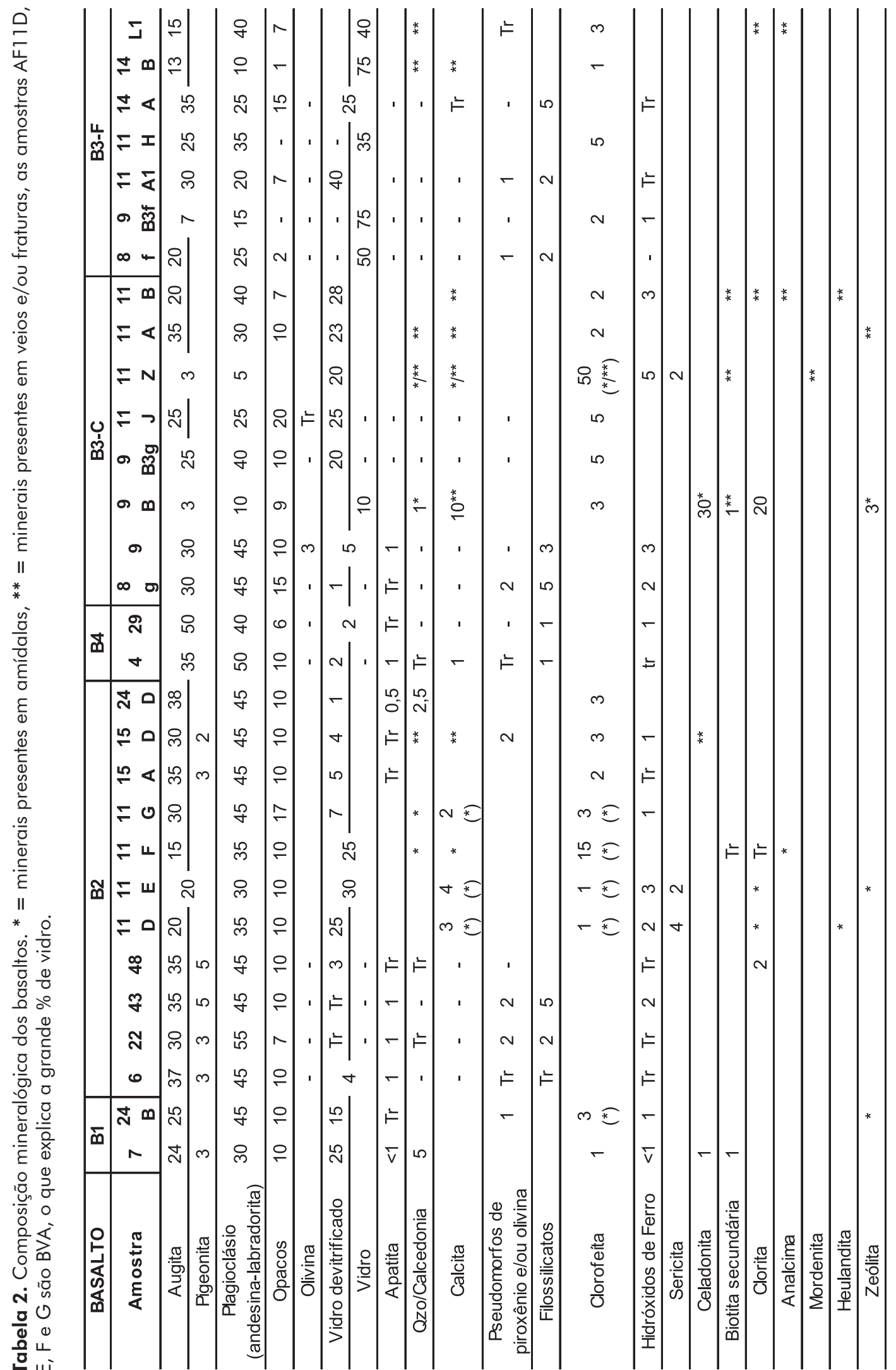


(Figura 6), que devem ter se formado também pela ascensão de diápiros de residuum.

A seção AA' (Figura 3) mostra tendência de diminuição de espessura de NE para SW. Nos AF7 e AF24 não foram observadas colunas, sendo que as fraturas presentes tendem a ser contínuas e planares ou onduladas. Parte destas fraturas corta também o nível B1-VA.

\section{Basalto 2 - B2}

O contato entre B1 e B2, em Bonfim Paulista, não foi observado em afloramentos, tendo sido posicionado com base na ocorrência do B1-VA do AF7 e das quebras de relevo negativas, situadas na base de encostas mais íngremes, como a que ocorre a noroeste e oeste do AF7 (Figura 3). No AF24, em Serrana (Figura 1), o contato entre B1 e B2 é marcado pela presença de arenito intertrappe pouco espesso, onde são observados 2 tipos de interação com os arenitos: 1) interação com B1, gerando brecha ou pseudopeperito; 2) interação com lava de B2, gerando um peperito. Na área de Bonfim Paulista, B2 repousa diretamente sobre B1-VA (Figura 5).

Com base no mapa geológico, a espessura estimada do derrame B2 é de 45 a $70 \mathrm{~m}$; a espessura identificada nos poços construídos foi de $64 \mathrm{~m}(\mathrm{~PB}), 58 \mathrm{~m}$ (PG) e de, pelo menos, $52 \mathrm{~m}(\mathrm{PL})$. Fenocristais milimétricos de piroxênio,

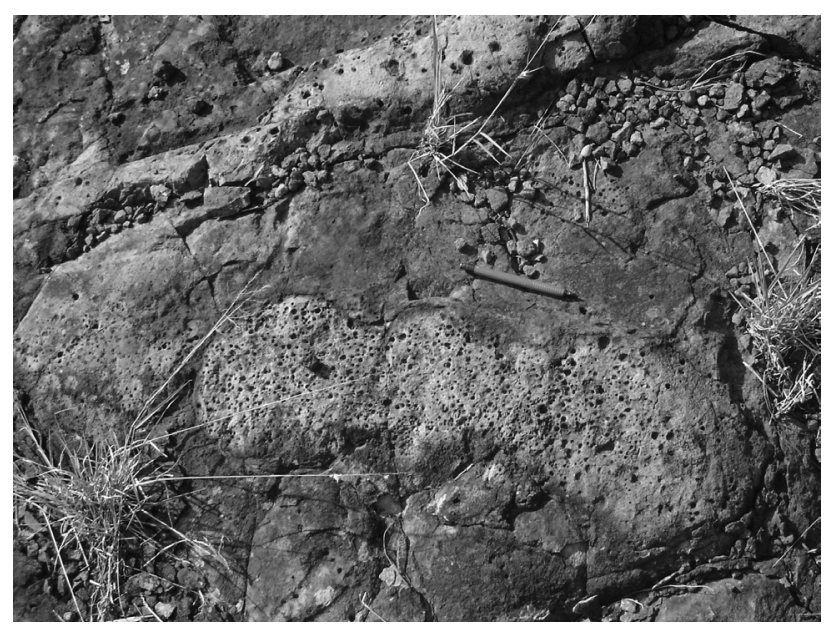

Figura 6. Basalto vesicular da porção superior de B1 (B1-VA) contendo porções mais claras com maior quantidade de vesículas e amídalas com relação às suas adjacências (AF7). Devem ter se formado por ascensão de diápiros de residuum durante o processo de colocação de magma por inflação. Aparecem tanto sob a forma de bolsões (centro da foto) como de veios (acima e à esquerda). com no máximo 8 mm, são típicos de B2 e, na ausência de outras feições, foram utilizados como evidência para identificação deste derrame. Ao microscópio caracteriza-se pelas texturas intergranular, porfirítica, intersertal e seriada, estrutura maciça e granulação fina a muito fina. Vidro devitrificado pode chegar a $5 \%$ no basalto denso e $30 \%$ no B2-VA (amostras 11D, E, F e G). Contém pequena quantidade de pseudomorfos de olivina e/ou piroxênios (Tabela 2). Em Bonfim Paulista e arredores, o B2 denso (porção central do derrame) foi observado nos AF6, AF10, AF22, AF40, AF41, AF42 e AF43.

Vesículas e amídalas estão presentes no topo do derrame, e foram observadas nos AF11, AF32, AF33, AF48 e AF49. No poço Brejinho (PB), observam-se dois níveis vesiculares na porção superior de B2 (Figura 5). Esta feição pode ser explicada por uma colocação pelo mecanismo de inflação para B2, mas a proporção da espessura de B2-VA com relação ao basalto denso, é inferior a $50 \%$. Apesar desta característica não ser imprescindível para derrames colocados por inflação, vale observar que não é encontrada em B2.

Quando presentes, as colunas de B2 são de formato irregular, e apresentam seção basal com diâmetro decimétrico; no entanto, o mesmo basalto apresenta porções sem colunas. A porção superior do AF22 caracteriza-se pela ausência de fraturas verticais, observando-se apenas as horizontais, o que deve indicar proximidade do limite superior do derrame.

O contato entre B2 e B3 foi melhor observado no AF11 e consiste, da base para o topo (Figura 7A), em:

1. B2-VA com amídalas preenchidas por carbonato (principalmente), clorofeíta/celadonita, analcima, calcedônia (às vezes fibrosa), quartzo microcristalino, clorita (pode ser fibrorradiada), zeólita (por vezes, heulandita) e óxidos de Fe. É comum a presença de fina película de clorofeíta ou celadonita, e eventualmente vidro basáltico, na borda de amídalas constituídas por minerais claros (principalmente, calcita). De um modo geral, as amídalas são envolvidas, total ou parcialmente, por vidro basáltico; algumas apresentam núcleo totalmente preenchido por vidro alterado (ao microscópio é castanho) e fina envoltória de quartzo microcristalino. Eventuais fraturas, observadas em lâmina, apresentam o mesmo tipo de preenchimento que o das amídalas. A composição da matriz do B2-VA está descrita na Tabela 2.

2. Camada descontínua, de espessura decimétrica, de arenito fino a médio, moderada a pobremente selecionado, constituído por grãos de quartzo monocristalino. O arcabouço está cimentado por sílica microcristalina, atribuível à percolação de fluidos hidrotermais derivados de B3, sendo os grãos de quartzo recobertos por filme de óxidos e hidróxidos de Fe que se espessa junto ao contato com 

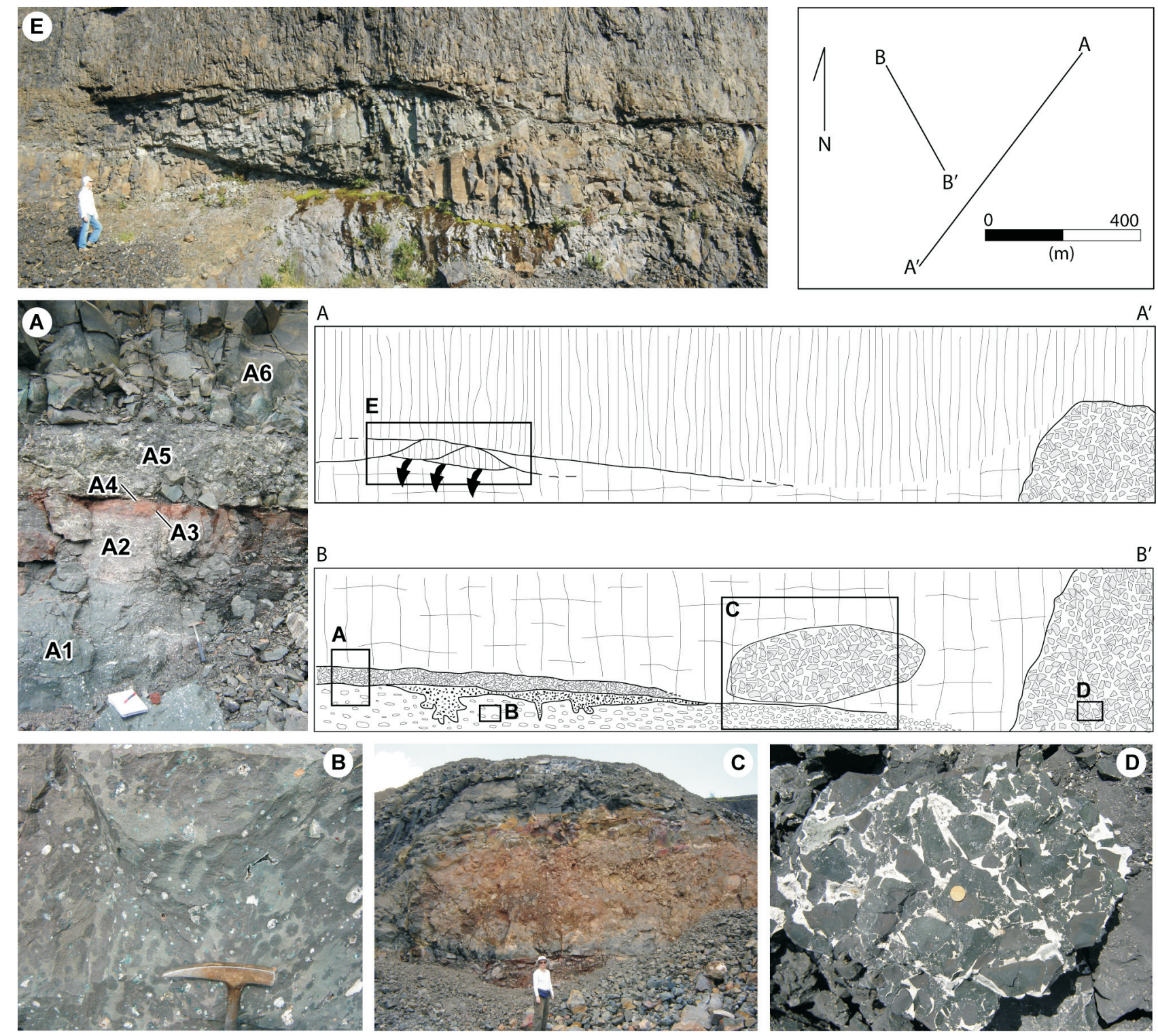

Figura 7. Croqui de parte do AF1 1. A. Contato B2/B3. (A1) Basalto vesicular da porção superior de B2 (B2-VA); (A2) brecha de fragmentos de B2-VA em matriz de arenitos de coloração avermelhada; (A3) Arenito pouco espesso de cor avermeIhada; (A4) Fratura sub-horizontal; (A5) brecha, de $80 \mathrm{~cm}$ de espessura, com fragmentos de B3-VA em matriz branca (detaIhes no texto); (A6) B3 com vesículas achatadas e amídalas, ambas milimétricas, esparsas. B. B2-VA de colorações variadas resultantes de processos de alteração causados por circulação heterogênea, tanto de líquidos hidrotermais, oriundos de B3, como de líquidos já mais frios (água subterrânea), produzindo alteração intempérica (detalhes no texto). C. Bolsão de brecha alterado na base de B3c, imediatamente acima de fraturas sub-horizontais localizadas entre B2 e B3. D. Brecha em bolsão na base de B3. E. Fraturas sub-horizontais, no contato entre B3-C e B3-E, configurando uma zona de cisalhamento. Notar presença de vegetação, acompanhada por saída de água, na fratura mais inferior. 
o basalto, originando, macroscopicamente, um filme de cor vermelho escuro, marcando tal contato. Diques clásticos oriundos deste arenito preenchem fraturas que cortam o B2-VA sotoposto. O contato arenito/B2-VA é irregular e com reentrâncias; entre ambos ocorre brecha de fragmentos de B2-VA em meio a arenito (pseudopeperitos, de acordo com Jerram e Stollhofen, 2002).

3. Camada tabular com $80 \mathrm{~cm}$ de espessura de brecha constituída por fragmentos de B3-VA e matriz de calcita bem cristalizada. Na porção basal da brecha, ocorrem fraturas horizontais, pouco espaçadas, preenchidas por calcita; suas superfícies são lisas, e podem apresentar estrias de atrito. Entre o arenito e a brecha ocorre nível centimétrico de arenito alterado, terroso, avermelhado a marrom escuro, contendo fraturas onde foi cristalizada calcita. Percolação de água acorre ainda atualmente ao longo de fraturas, explicando a alteração intensa.

4. B3 com vesículas achatadas e amídalas, ambas milimétricas, mais ou menos esparsas.

As brechas de fragmentos de B2-VA em matriz de arenito e o B2-VA do AF11 apresentam colorações variadas resultantes de processos de alteração causados por circulação heterogênea, tanto de líquidos hidrotermais, oriundos de B3 (já que atuaram posteriormente à deposição dos arenitos, que recobrem B2), como de líquidos já mais frios (água subterrânea), produzindo alteração intempérica (Figura 7B). Tal circulação dá-se, preferencialmente, ao longo de fraturas sub-horizontais presentes na base de B3, as quais ainda são ativas hidraulicamente (presença de saídas de água) e produziram a intensa alteração de parte do arenito descrito acima. Macroscopicamente observam-se as seguintes cores:

1. B2-VA cinza esverdeado ou cinza médio em contato com arenito avermelhado. A cor do B2-VA é devida ao maior grau de alteração hidrotermal, caracterizado, principalmente, por presença de grande quantidade de amídalas inteiramente verdes, constituídas de celadonita, presença abundante de clorofeíta verde claro na mesóstase do basalto (tanto a celadonita como a clorofeíta são provenientes de alteração de vidro), e feldspatos muito alterados a carbonato e sericita. Também estão presentes amídalas vermelho vivo (alteração de vidro ou de calcita) e friáveis; as amídalas de calcita têm uma película de celadonita nas bordas. $\mathrm{O}$ arenito é avermelhado devido à presença de hidróxidos de $\mathrm{Fe}$, que são mais abundantes em faixa milimétrica, de cor vermelho escuro, adjacente ao BVA.

2. B2-VA cinza médio em contato com arenito cinzaclaro. O B2-VA apresenta-se menos alterado, os feldspatos são límpidos e tanto nas vesículas como nas amídalas ocorre preenchimento preto (ao microscópio, trata-se de clorofeíta marrom esverdeada), em vez de celadonita. O vidro intersticial do basalto é marrom e mais escuro, em parte já passando para clorofeíta, mas esta ainda é marrom esverdeada. Os arenitos são acinzentados e não avermelhados, ou seja, não apresentam hidróxidos de Fe.

3. Entre os dois B2-VA acima descritos, ocorre mistura de porções mutuamente penetrantes de: B2-VA cinza-esverdeado e B2-VA cinza mais escuro com matiz avermelhado (Figura 7B). Esta última contém mais hidróxidos de $\mathrm{Fe}$, os feldpspatos são acastanhados, indicando um princípio de alteração intempérica, além de amídalas pulverulentas de cor vermelho forte. Nas porções cinza esverdeadas, os feldspatos estão mais límpidos. Ambas as porções contêm amídalas e pequenos geodos preenchidos por calcita e/ou quartzo, ambos com bordas verdes de celadonita. Os contatos entre estas porções são bastante nítidos, abruptos e sinuosos.

Brechas superpostas por arenitos pouco espessos no contato de B2 com B3 também foram observadas nos AF32, AF33, AF41 e AF44. No poço Galo Vermelho (PG), observam-se dois níveis de arenito intertrappe, no limite superior do derrame B2 (Figura 5), sendo que o nível inferior é mais coeso e vermelho, enquanto o superior é bege e friável. A existência destes dois níveis pode ser devida a: 1) o superior foi colocado por injeção de baixo para cima, devido à explosão causada pelo avanço de lava sobre arenito saturado de água (tal injeção tem o nome de spiracle); ou 2) o basalto, quando da colocação, engolfou um pedaço de arenito. A cor avermelhada do nível inferior de arenito é devida à deposição de película de óxidos e hidróxidos de $\mathrm{Fe}$ em torno dos grãos de quartzo, associada à circulação de água subterrânea. A camada de arenitos chega a $5 \mathrm{~m}$ de espessura e, junto ao contato com B3, apresenta faixa centimétrica dura e avermelhada, caracterizada pela maior quantidade de hidróxidos de Fe.

\section{Basalto 3 - B3}

O B3 é afanítico, e apresenta espessura total que varia de 75 (próximo ao AF5) a 105 m (entre AF31a e AF49), como indicado pelo mapa geológico (Figura 3). É caracterizado por duas porções distintas:

1. Uma inferior, com espessuras estimadas de 15 a $20 \mathrm{~m}$, onde as colunas apresentam seção basal decimétrica (os lados das colunas medem desde $10 \mathrm{~cm}$ a até $75 \mathrm{~cm}$ e o diâmetro varia de 50 a $160 \mathrm{~cm}$ ). É descrita na literatura como colunada (ver explicação mais abaixo), sendo aqui denominada de B3-C.

2. Uma superior e bem mais espessa (pelo menos $60 \mathrm{~m}$ ), onde as colunas são mais finas (Figura 8A). É des- 
crita na literatura como entablamento (ver explicação mais abaixo), sendo aqui denominada de B3-E. B3-E apresenta colunas de primeira e segunda ordem, com lados de cerca de 15 a $30 \mathrm{~cm}$ e de 5 a $10 \mathrm{~cm}$, respectivamente (Figura 8B), sendo que estas ordens também correspondem à cronologia relativa de sua formação. A seção das colunas finas, de segunda ordem, é muito irregular, apresentando, em geral, quatro ou cinco lados, e as fraturas que as delimitam apresentam feições conspícuas em costela, típicas de fraturas extensionais, neste caso, geradas por resfriamento. As colunas de primeira ordem apresentam seção mais regular grosseiramente com 6 lados, e as superfícies das fraturas que as delimitam são bem menos rugosas e recobertas por uma película verde escuro. Supõe-se que as fraturas de primeira ordem, após se formarem, permitiriam convecção de fluidos (melhor discutida abaixo), o que ocasionaria um resfriamento mais rápido e a formação das fraturas de segunda ordem. Em alguns setores do AF9, nota-se que as colunas de B3-C passam continuamente para o B3-E. Vênulas brancas de espessura submilimétrica selam os es-
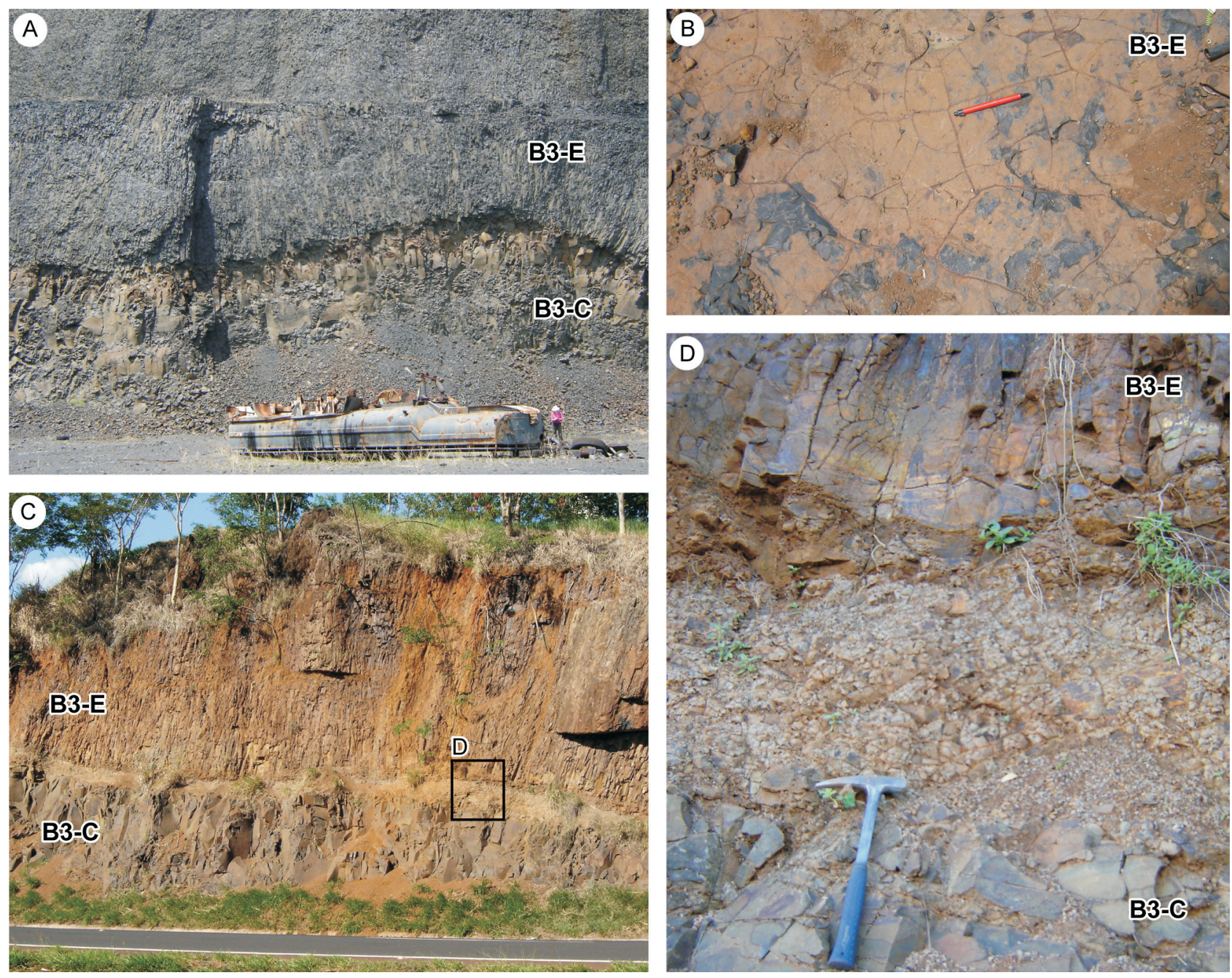

Figura 8. A. Contato ondulado entre B3-C, na base, e B3-E, no topo (AF9, Pedreira Inderp). B. Duas ordens de disjunções em B3-E, uma decimétrica (lapizeira paralela ao lado de uma das colunas) e outra centimétrica contida na primeira (AF 50). C. Aspecto geral da porção leste do AF8 mostrando basalto com fraturas de espaçamento decimétrico (B3-C), abaixo, e basalto com fraturas de espaçamento centimétrico (B3-E), acima. D. detalhe da camada mais clara que separa os basaltos em (B). Esta camada contém veios sub-horizontais de sílica microcristalina ou zeólitas e fraturas predominantemente de médio a baixo ângulo (detalhes no texto). 
paços entre as colunas de $\mathrm{B} 3-\mathrm{E}$, junto às quais o basalto apresenta halos mais escuros de $0,5 \mathrm{~cm}$ de alteração. Estas vênulas indicam a atuação de atividade hidrotermal após a geração das colunas.

Para os derrames basálticos da Bacia do Paraná, entablamento foi descrito por Souza Jr. (1992) e por Gomes e Rodrigues (1999) em vários municípios paulistas, incluindo Ribeirão Preto, São Carlos e Araraquara, sendo que um dos afloramentos mencionados pelos autores é a pedreira Inderp, que corresponde ao AF9. Os termos entablature (entablamento) e colonnade (colunada) foram definidos por Tomkeieff (1940, apud Long e Wood, 1986). O entablamento, observado em $60 \%$ dos derrames de basaltos Grande Ronde na porção central do Columbia Plateau, uma das principais províncias continentais de efusivas toleíticas, é causado por esfriamento extremamente rápido o qual requer o mecanismo de correntes de convecção de água ao longo das primeiras fraturas geradas (Long e Wood, 1986). A água teria origem principal em inundações ocasionadas por desorganização da drenagem, devido a extravasamentos volumosos de lava; evidências de derrames atuais sugerem que chuvas torrenciais, por si sós, não seriam suficientes para formar entablamentos (Long e Wood, 1986).

O diâmetro das colunas, cuja formação é governada pela atuação conjunta de transferência de calor por condução e convecção (esta ocorre devido aos líquidos que percolaram os espaços entre as fraturas mais precoces), sugere que seja inversamente proporcional à velocidade de resfriamento. Assim, o front de solidificação avança $2,1 \mathrm{~m} / \mathrm{ano}$ para colunas de $4 \mathrm{~m} ; 8,4 \mathrm{~m} / \mathrm{ano}$ para colunas de $1 \mathrm{~m}, 40 \mathrm{~m} /$ ano para colunas de $0,2 \mathrm{~m}$ (Budkewitsch e Robin, 1994). Devido às espessuras de B3, entre 75 e 105 m, e ao diâmetro das colunas do entablamento, em média menor que $20 \mathrm{~cm}$ (Figura 8B), é possível sugerir que $\mathrm{B} 3$ tenha se solidificado em um período de tempo da ordem de 2 anos. Notar que Budkewitsch e Robin (1994) não mencionam qual é a natureza do líquido que circula convectivamente nas fraturas. A possível influência de outros fatores, tais como conteúdo de água no magma, gases vulcânicos, ou cinemática da colocação do derrame, para a geração do entablamento, a princípio, não pode ser descartada (Long e Wood, 1986).

Ao microscópio, B3-C apresenta granulação muito fina e 1 a $28 \%$ de vidro devitrificado (Tabela 3); B3-E é muito fino a vítreo, contendo 25 a $75 \%$ de vidro (por vezes em gotas, ou seja, porções arredondadas de dimensões submilimétricas), indicando resfriamento muito rápido, o que é compatível com o entablamento. Long e Wood (1986) descrevem 35 a $65 \%$ de vidro e vidro devitrificado na porção de entablamento. A estrutura maciça a fracamente fluidal, e as texturas intersertal e hialopilítica (Tabela 3), indicam baixa viscosidade do magma.

Outra feição marcante de B3 é a presença de bolsões de brechas hidráulicas contidos em B3-C (Figuras 7C e 7D), junto ou próximos ao contato com B2. Constituem-se de fragmentos angulosos de B3-VA cinza escuro com amídalas pretas e vesículas, ambas milimétricas. A matriz da brecha na amostra AF11-Z (Tabela 2), é branca e consiste em zeólitas (mordenita) fibrosas que, mais longe das paredes dos fragmentos de basalto, ficam acinzentadas, e formam alguns cristais euédricos; próximo ao contato com os fragmentos, a matriz contém quantidades menores de calcita, quartzo, sílica microcristalina e clorofeíta.

Uma das características marcantes dos basaltos com entablamento é a sua maior espessura, fato confirmado na área de estudo onde B3 (75 a $105 \mathrm{~m}$ ) é bem mais espesso que os outros derrames, que não apresentam entablamento. Isto sugere que espessuras semelhantes às de B3 não são raras na Bacia do Paraná. De acordo com o observado no campo, B3 é do tipo III, que, segundo Long e Wood (1986), corresponde a derrame com um nível central de entablamento, delimitado na base e no topo por níveis colunada. No entanto deve-se lembrar que os afloramentos não são contínuos para se afirmar categoricamente que B3 possui apenas uma camada central com entablamento.

A superfície de contato entre B3-E e B3-C, nos AF8 e 9, é bastante ondulada (Figura 8). No AF8 (Figuras 8C e 8D), observou-se, entre B3-C e B3-E, um nível de espessura de $0,5 \mathrm{~m}$, sem colunas, mas com veios descontínuos e sub-horizontais, constituídos de material branco leitoso que não efervesce com ácido (sílica microcristalina ou zeólitas), e muitas fraturas de médio ângulo a sub-horizontais. O padrão de fraturas deste nível assemelha-se ao dos entablamentos descritos por Katternhorn e Schaefer (2008), para derrames colocados pelo mecanismo de inflação, e representariam a porção final de lava a resfriar, indicando assim a localização exata de lava fluida anterior à solidificação completa. $\mathrm{O}$ resfriamento desta lava seria muito rápido devido à percolação convectiva de água oriunda da superfície ao longo de fraturas de inflação que atingiriam este nível. Katternhorn e Schaefer (2008) observaram este tipo de entablamento em derrames pouco espessos, o que faz levantar a possibilidade de B3, neste local, ser menos espesso. No entanto não há dados conclusivos a este respeito. Os mecanismos associados à geração deste tipo de entablamento são discutidos em outro trabalho (Fernandes, Rouleau, Maldaner, em preparação).

Fraturas sub-horizontais ou de mergulho baixo, por vezes em padrão lenticular e anastomosado, com extensão lateral da ordem de centenas de metros e superfícies lisas e estriadas, podem ocorrer no contato entre B2 e B3 (Figura 7A) e entre B3-C e B3-E (Figura 7E). Estas fraturas 
Tabela 3. Textura, estrutura e granulação, observadas ao microscópio, dos basaltos da área de estudo. ${ }^{* * *},{ }^{* *} \mathrm{e}^{*}=$ re- $^{*}$ presenta característica em ordem decrescente de importância para a amostra analisada.

\begin{tabular}{|c|c|c|c|c|c|c|c|c|c|c|c|c|c|c|c|}
\hline Grupo & \multicolumn{2}{|c|}{ B1 } & \multicolumn{11}{|c|}{ B2 } & \multicolumn{2}{|c|}{ B4 } \\
\hline AMOSTRA & 7 & $\begin{array}{r}24 \\
\text { B }\end{array}$ & 6 & 22 & 43 & 48 & $\begin{array}{c}11 \\
\text { D }\end{array}$ & $\begin{array}{c}11 \\
\mathrm{E}\end{array}$ & $\begin{array}{c}11 \\
F\end{array}$ & $\begin{array}{l}11 \\
\text { G }\end{array}$ & $\begin{array}{c}15 \\
\text { A }\end{array}$ & $\begin{array}{c}15 \\
\text { D }\end{array}$ & $\begin{array}{c}24 \\
\text { D }\end{array}$ & 4 & 29 \\
\hline \multicolumn{16}{|c|}{ Textura } \\
\hline Intersertal & ${ }^{*}$ & * & ** & ** & ** & ${ }^{*}$ & $* *$ & ** & ${ }^{* *}$ & ** & * & * & & ** & * \\
\hline Porfirítica & & & & & & ** & * & * & * & * & & ** & & & \\
\hline Intergranular & & & & $* * *$ & *** & & & & & & & & $* *$ & $* * *$ & $* *$ \\
\hline Seriada & & & ${ }^{*}$ & * & ${ }^{*}$ & & & & & & & & & & \\
\hline Glomeroporfirítica & & & & & & & & & & & $* *$ & & & * & *** \\
\hline Microporfirítica & ${ }^{*}$ & & & & & & & & & & & & & & \\
\hline Micropegmatítica & & & & & & & & & & & & & * & & \\
\hline \multicolumn{16}{|c|}{ Estrutura } \\
\hline Maciça & ${ }^{*}$ & ${ }^{*}$ & ${ }^{*}$ & * & ${ }^{*}$ & ${ }^{*}$ & * & * & * & * & ${ }^{*}$ & * & * & ${ }^{*}$ & * \\
\hline \multicolumn{16}{|l|}{ Fluidal } \\
\hline Presença de amídalas (\%) & & $2 \%$ & & & & & $20 \%$ & $15 \%$ & $3 \%$ & $50 \%$ & & & & & \\
\hline \multicolumn{16}{|l|}{ Veios } \\
\hline \multicolumn{16}{|c|}{ Granulação } \\
\hline Muito fina & & & * & * & * & & & & & & & & & * & * \\
\hline Fina & ${ }^{*}$ & * & ${ }^{*}$ & * & * & * & * & * & * & * & * & * & * & & \\
\hline Média & & & ${ }^{*}$ & & & & & & & & & & & & \\
\hline \multicolumn{16}{|c|}{ Observações } \\
\hline Hidrotermalismo & & & & & & & * & * & * & * & & & & & \\
\hline Grupo & \multicolumn{8}{|c|}{ B3-C } & \multicolumn{7}{|c|}{ B3-E } \\
\hline AMOSTRA & 8 & 9 & 9 & 9 & 11 & 11 & 11 & 11 & 8 & 9 & 11 & 11 & 14 & 14 & 11 \\
\hline 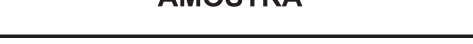 & $\mathbf{g}$ & 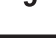 & B & B3g & A & B & $J$ & $\mathbf{Z}$ & $\mathbf{f}$ & B3f & A1 & $\mathbf{H}$ & A & B & Li \\
\hline \multicolumn{16}{|c|}{ Textura } \\
\hline Intersertal & ${ }^{*}$ & ${ }^{*}$ & & * & & & & ** & & & & & * & & * \\
\hline Hialopilítica & & & ${ }^{*}$ & & * & & ** & * & * & * & & * & & * & \\
\hline Intergranular & ** & & & & & & & & & & & & & & \\
\hline Pilotaxítica & & & & & & * & & & & & & & & & \\
\hline Traquitóide & & & & & & & * & & & & & & & & \\
\hline \multicolumn{16}{|c|}{ Estrutura } \\
\hline Maciça & ** & ** & & * & * & & & * & ** & * & ** & * & * & * & * \\
\hline Fluidal & ${ }^{*}$ & ${ }^{*}$ & & & & & * & & * & & * & & & & \\
\hline Brechada & & & * & & & * & & * & & & & & & & \\
\hline Presença de amídalas & & & ${ }^{*}$ & & & & & $50 \%$ & 列 & & & 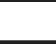 & & & \\
\hline Presença de veios (\%) & & & & & $5 \%$ & & & $00 \%$ & & & & & & & $70 \%$ \\
\hline Micrólitos de plagioclásio e piroxênio & & & * & & & & & & & & & & & & \\
\hline \multicolumn{16}{|c|}{ Granulação } \\
\hline Vítrea & & * & & & & & & & ** & * & $* *$ & * & * & ${ }^{*}$ & \\
\hline Muito fina & * & & * & * & * & * & * & * & * & & * & & ** & ** & * \\
\hline
\end{tabular}


associam-se a níveis de brechas de espessura centimétrica a decimétrica (Figura 7A; entre B3-C e B3-E a espessura é menor que $20 \mathrm{~cm}$ ), constituídos por fragmentos de basalto afanítico alterado, marrom avermelhado, em matriz esverdeada (clorofeíta, hidrobiotita) ou branca (quartzo microcristalino, calcita e zeólitas), por vezes amarronzada (argilomineral ferruginoso) (Amostras AF11A e B, Tabela 2). Saídas de água foram observadas em vários trechos destas fraturas, e várias evidências indicam que ao longo de tais estruturas fluíram tanto líquidos hidrotermais (alteração de B2-VA e de arenitos descrita acima) como água subterrânea, produzindo a alteração intempérica de arenito, no contato B2-B3, e de bolsão de brecha hidráulica de $\mathrm{B} 3$, disposto na continuidade e imediatamente acima das fraturas presentes no mesmo contato (Figura 7C). Tal brecha dispõe-se abaixo de dezenas de metros de B3 inalterado.

As brechas hidráulicas, em bolsões ou acompanhando as fraturas sub-horizontais de grande extensão (Figuras 7A, 7C e 7D), e a alteração hidrotermal, que afeta os arenitos no contato B2 e B3 e a porção superior de B2VA, indicam a abundância de fluidos residuais derivados de B3 que se acumularam em porções específicas. É possível que a penetração de águas de chuva e/ou inundações, também tenha contribuído para a maior presença de fluidos no derrame.

\section{Basalto 4 - B4}

O B3 é recoberto pelo B4 (Figura 3), observado nos AF4 e AF29 a AF31b, mas o contato não foi observado diretamente. O B4 ocorre apenas na porção SE do mapa de detalhe da região de Bonfim Paulista. Não foi possível determinar sua espessura, pelo fato de já estar parcialmente erodido. Trata-se de basalto afanítico a fanerítico muito fino com textura glomeroporfirítica e estrutura maciça. Possivelmente, o magma iniciou cristalização em profundidade $\mathrm{e}$, ao ser expulso, o resfriamento foi rápido, formando matriz fina a vítrea (intergranular a intersertal). A amostra AF4 (Tabela 2) contém cavidade irregular, preenchida por carbonato, indicando que pode estar próxima da base ou topo do derrame. Exibe pequenas fraturas "em colher" e fraturas subverticais de espaçamento, em geral, decimétrico ou métrico, em parte tectônicas. As colunas, quando presentes, exibem diâmetro maior que $50 \mathrm{~cm}$, sendo, ocasionalmente, maior que $1 \mathrm{~m}$. As superfícies de alteração dos blocos de B4 podem apresentar concavidades semiesféricas e sulcos que imitam laminação ou estratificação, provavelmente relacionados a acamamento magmático horizontal (sucessão de camadas finas com até $10 \mathrm{~cm}$ de espessura), causado por fluxo magmático, como descrito por Nardy et al. (2002).

\section{Geoquímica}

A Figura 9 mostra que as rochas básicas da região de Ribeirão Preto são classificadas principalmente como basaltos e secundariamente como andesitos basálticos, quando representadas no diagrama TAS. A Tabela 5 apresenta os dados geoquímicos completos e a Tabela 4, a classificação dos basaltos da área de estudo baseada em Peate, Hawkesworth e Mantovani (1992). Os basaltos B1, B2 e B3 são de alto Ti e compatíveis com o tipo Pitanga. Basaltos com 50 a $90 \%$ de vidro, de Ribeirão Preto, apresentam teores de Ti ainda mais elevados $(3,37 \% \leq \mathrm{TiO} 2 \geq 4,47 \%)$ (Nardy et al., 2005). Nota-se que é o caso de B3 na presente área de estudo.

A estratigrafia estabelecida com base em dados de afloramentos e dos poços perfurados foi corroborada pelas análises químicas, sendo que $\mathrm{B} 3$ é perfeitamente distinguível de $\mathrm{B} 2$ e $\mathrm{B} 1$ com relação a vários óxidos $\left(\mathrm{Al}_{2} \mathrm{O}_{3}, \mathrm{P}_{2} \mathrm{O}_{5}\right.$, $\mathrm{TiO}_{2}$ e $\mathrm{MgO}$ ) e elementos traço (Ni, $\mathrm{Zn}, \mathrm{Cu}, \mathrm{Y}$ ) em função dos valores de $\mathrm{SiO}_{2}$ (Figura 10); com relação aos valores de $\mathrm{MgO} / \mathrm{TiO}_{2}$, além dos componentes já citados, os teores de $\mathrm{Fe}_{2} \mathrm{O}_{3}$ também são diferenciados (Figura 11). A utilização da razão $\mathrm{MgO} / \mathrm{TiO}_{2}$, como índice de diferenciação, foi indicada verbalmente pelo professor Valdecir Janasi e, de fato, parece adequado para as rochas em estudo, em que $\mathrm{MgO}$ diminui com o fracionamento, enquanto $\mathrm{TiO}_{2}$ aumenta. A distinção entre $\mathrm{B} 1$ e $\mathrm{B} 2$ restringe-se aos óxidos $\mathrm{P}_{2} \mathrm{O}_{5}$ e $\mathrm{TiO}_{2}$ e a poucos elementos menores $(\mathrm{Cu}$, e secundariamente, Zn, Y e Ni) (Figura 11); comportamen-

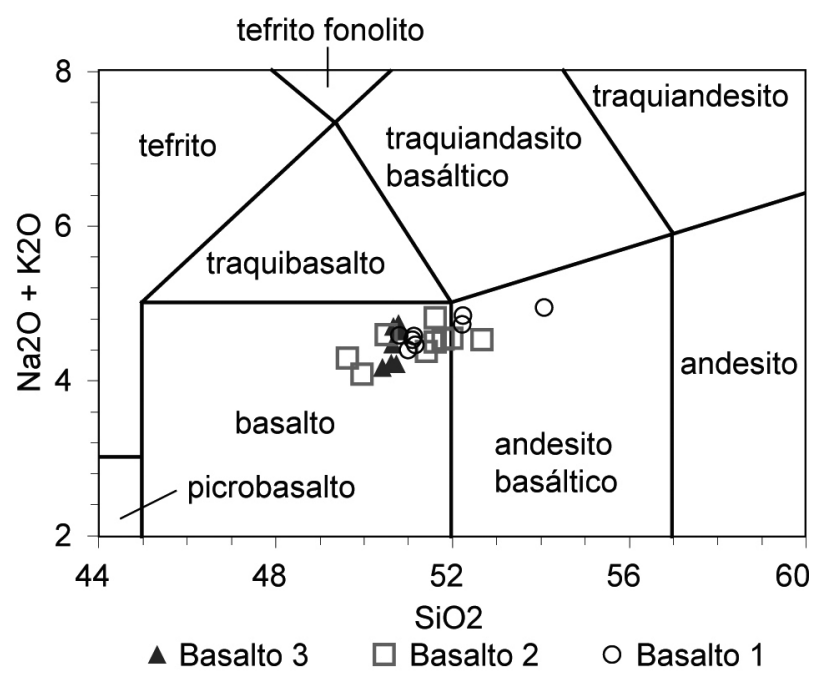

Figura 9. Diagrama TAS (Le Bas et al., 1986) mostrando que as rochas básicas da região de Ribeirão Preto são classificadas principalmente como basaltos e secundariamente como andesitos basálticos. 
to semelhante é observado nos gráficos $\mathrm{MgO} / \mathrm{TiO}_{2}$ (Figura 11). As amostras PPE1-94m (B1), nos gráficos de abscissa $\mathrm{MgO} / \mathrm{TiO}_{2}$, ficam mais próximas de $\mathrm{B} 3$ do que das outras amostras de $\mathrm{B} 1$ para o Ni, Y, Z, V e $\mathrm{Fe}_{2} \mathrm{O}_{3}$. Supõese que isto pode ter sido causado pelo fato das porções basais de B1, esfriadas mais precocemente, não permitirem processos de diferenciação. As concentrações de óxidos e elementos traço para as várias amostras de B3, com exceção do $\mathrm{Na}_{2} \mathrm{O}$, são muito pouco variáveis, possivelmente devido ao esfriamento muito rápido, o que, da mesma forma que para a porção basal de B1, não permitiu uma diferenciação. Sugere-se processo de diferenciação magmática em função da profundidade no derrame B2, pois todas as amostras coletadas em profundidades maiores em poços (PL 48-50, PL 44-46 e PPE1-42) apresentam teor de $\mathrm{SiO}_{2}<50,5 \%$ (Tabela 5), ao passo que aquelas de afloramentos, situadas, provavelmente, em níveis mais rasos de $\mathrm{B} 2$, bem como amostra mais próxima à superfície no PL (PL 18-20), contém teores de $\mathrm{SiO}_{2}>51 \%$. Além disso, as amostras com $\mathrm{SiO}_{2}<50,5 \%$, apresentam teores de $\mathrm{Mg}$, Ti e Fe mais elevados e de $\mathrm{K}$ e $\mathrm{Zr}$ mais baixos, quando comparadas às amostras com $\mathrm{SiO} 2>51 \%$ (Figura 10 ). O maior conteúdo de sílica das amostras AF6, 22, 43 e 48 não é causado por feições secundárias, pois se verificou, nas seções delgadas, que estas não contêm microvesículas ou veios.

Tabela 4. Dados geoquímicos completos das amostras.

\begin{tabular}{|c|c|c|c|c|c|c|c|c|c|c|c|c|c|}
\hline \multicolumn{2}{|c|}{ Amostra } & \multirow{2}{*}{$\begin{array}{c}\text { AF6 } \\
08 / 091\end{array}$} & \multirow{2}{*}{$\begin{array}{c}\text { AF8-B2 } \\
08 / 092 \\
\end{array}$} & \multirow{2}{*}{$\begin{array}{c}\text { AF8-B3 } \\
08 / 093 \\
\end{array}$} & \multirow{2}{*}{$\begin{array}{c}\text { AF9-B3f } \\
08 / 094 \\
\end{array}$} & \multicolumn{2}{|c|}{ AF9-B3g } & \multirow{2}{*}{$\begin{array}{c}\text { AF11-J } \\
08 / 096 \\
\end{array}$} & \multirow{2}{*}{$\begin{array}{c}\text { AF11-H } \\
08 / 097 \\
\end{array}$} & \multirow{2}{*}{$\begin{array}{l}\text { AF22 } \\
08 / 098 \\
\end{array}$} & \multirow{2}{*}{$\begin{array}{l}\text { AF43 } \\
08 / 099\end{array}$} & \multicolumn{2}{|c|}{ AF48 } \\
\hline Núme & ro Lab. & & & & & 08/095a & 08/095b & & & & & $08 / 100 a$ & $08 / 100 \mathrm{~b}$ \\
\hline $\mathrm{SiO} 2$ & $(\%)$ & 51,60 & 50,78 & 50,65 & 50,62 & 50,42 & 50,73 & 50,79 & 50,67 & 51,60 & 51,40 & 51,78 & 51,99 \\
\hline $\mathrm{Al} 2 \mathrm{O} 3$ & $(\%)$ & 12,69 & 12,50 & 12,43 & 12,32 & 12,32 & 12,41 & 12,38 & 12,33 & 12,69 & 12,80 & 12,75 & 12,77 \\
\hline $\mathrm{MnO}$ & $(\%)$ & 0,203 & 0,220 & 0,220 & 0,219 & 0,214 & 0,215 & 0,217 & 0,217 & 0,201 & 0,213 & 0,195 & 0,195 \\
\hline $\mathrm{MgO}$ & $(\%)$ & 4,10 & 3,94 & 3,97 & 3,89 & 3,83 & 3,89 & 3,95 & 3,90 & 4,08 & 4,13 & 4,10 & 4,11 \\
\hline $\mathrm{CaO}$ & $(\%)$ & 7,90 & 7,91 & 7,99 & 7,98 & 7,87 & 7,89 & 7,86 & 7,90 & 8,03 & 8,00 & 7,67 & 7,67 \\
\hline $\mathrm{Na} 2 \mathrm{O}$ & $(\%)$ & 2,72 & 3,04 & 3,02 & 2,79 & 2,70 & 2,75 & 3,33 & 3,27 & 3,14 & 2,72 & 2,76 & 2,77 \\
\hline $\mathrm{K} 2 \mathrm{O}$ & $(\%)$ & 1,78 & 1,70 & 1,46 & 1,44 & 1,47 & 1,47 & 1,32 & 1,43 & 1,68 & 1,66 & 1,78 & 1,78 \\
\hline TiO2 & $(\%)$ & 3,391 & 3,875 & 3,913 & 3,914 & 3,862 & 3,844 & 3,848 & 3,865 & 3,426 & 3,480 & 3,337 & 3,336 \\
\hline P2O5 & $(\%)$ & 0,431 & 0,641 & 0,626 & 0,633 & 0,629 & 0,631 & 0,633 & 0,628 & 0,444 & 0,436 & 0,434 & 0,430 \\
\hline $\mathrm{Fe} 2 \mathrm{O} 3$ & $(\%)$ & 14,67 & 15,58 & 15,55 & 15,55 & 15,49 & 15,55 & 15,66 & 15,64 & 14,86 & 14,84 & 14,75 & 14,74 \\
\hline Loi & $(\%)$ & 0,20 & 0,22 & 0,13 & 0,20 & 0,36 & 0,40 & 0,24 & 0,18 & 0,26 & 0,12 & 0,18 & 0,18 \\
\hline Total & $(\%)$ & 99,69 & 100,41 & 99,96 & 99,56 & 99,17 & 99,78 & 100,23 & 100,03 & 100,41 & 99,80 & 99,74 & 99,97 \\
\hline $\mathrm{Ba}$ & $(\mathrm{mg} / \mathrm{kg})$ & 475 & 520 & 509 & 528 & 535 & 542 & 531 & 537 & 455 & 473 & 494 & 500 \\
\hline $\mathrm{Ce}$ & $(\mathrm{mg} / \mathrm{kg})$ & 128 & 114 & 109 & 142 & 136 & 119 & 125 & 111 & 115 & 108 & 94 & 91 \\
\hline Co & (mg/kg) & 32 & 34 & 39 & 36 & 35 & 34 & 32 & 37 & 34 & 33 & 32 & 32 \\
\hline $\mathrm{Cr}$ & $(\mathrm{mg} / \mathrm{kg})$ & 18 & $<13$ & 14 & $<13$ & $<13$ & $<13$ & 13 & $<13$ & 17 & 13 & 16 & 14 \\
\hline $\mathrm{Cu}$ & $(\mathrm{mg} / \mathrm{kg})$ & 128 & 173 & 166 & 165 & 160 & 162 & 160 & 167 & 126 & 126 & 118 & 119 \\
\hline $\mathrm{Ga}$ & $(\mathrm{mg} / \mathrm{kg})$ & 26 & 24 & 24 & 25 & 24 & 26 & 25 & 25 & 23 & 24 & 25 & 24 \\
\hline La & $(\mathrm{mg} / \mathrm{kg})$ & 52 & 42 & 32 & 36 & 44 & 36 & 63 & 54 & 30 & 35 & 30 & 52 \\
\hline $\mathrm{Nb}$ & $(\mathrm{mg} / \mathrm{kg})$ & 24 & 28 & 27 & 27 & 27 & 28 & 28 & 28 & 22 & 23 & 24 & 24 \\
\hline $\mathrm{Nd}$ & (mg/kg) & 60 & 63 & 70 & 78 & 54 & 72 & 64 & 76 & 60 & 56 & 58 & 70 \\
\hline $\mathrm{Ni}$ & $(\mathrm{mg} / \mathrm{kg})$ & 25 & 23 & 23 & 22 & 21 & 19 & 21 & 22 & 25 & 25 & 25 & 24 \\
\hline $\mathrm{Pb}$ & $(\mathrm{mg} / \mathrm{kg})$ & 15 & 15 & 18 & 17 & 14 & 13 & 15 & 13 & 16 & 16 & 13 & 14 \\
\hline $\mathrm{Rb}$ & $(\mathrm{mg} / \mathrm{kg})$ & 35 & 33 & 34 & 31 & 33 & 33 & 33 & 33 & 32 & 33 & 35 & 35 \\
\hline Sc & $(\mathrm{mg} / \mathrm{kg})$ & 28 & 31 & 32 & 32 & 32 & 30 & 34 & 32 & 28 & 32 & 29 & 30 \\
\hline $\mathrm{Sr}$ & $(\mathrm{mg} / \mathrm{kg})$ & 476 & 491 & 497 & 493 & 496 & 497 & 505 & 495 & 480 & 484 & 473 & 472 \\
\hline Th & $(\mathrm{mg} / \mathrm{kg})$ & 13 & 14 & 13 & 14 & 14 & 12 & 12 & 12 & 15 & 15 & 12 & 12 \\
\hline U & $(\mathrm{mg} / \mathrm{kg})$ & 7 & 7 & 7 & 8 & 8 & 7 & 7 & 7 & 7 & 6 & 7 & 5 \\
\hline V & $(\mathrm{mg} / \mathrm{kg})$ & 420 & 410 & 397 & 387 & 392 & 384 & 354 & 380 & 392 & 441 & 435 & 400 \\
\hline $\mathrm{Y}$ & (mg/kg) & 37 & 41 & 40 & 41 & 41 & 41 & 41 & 41 & 36 & 36 & 37 & 37 \\
\hline $\mathrm{Zn}$ & $(\mathrm{mg} / \mathrm{kg})$ & 128 & 144 & 145 & 145 & 141 & 142 & 141 & 145 & 128 & 126 & 126 & 125 \\
\hline $\mathrm{Zr}$ & $(\mathrm{mg} / \mathrm{kg})$ & 285 & 303 & 301 & 302 & 303 & 305 & 304 & 304 & 275 & 276 & 286 & 286 \\
\hline $\mathrm{Cl}$ & $(\mathrm{mg} / \mathrm{kg})$ & $<50$ & $<50$ & $<50$ & $<50$ & $<50$ & $<50$ & $<50$ & $<50$ & $<50$ & $<50$ & $<50$ & $<50$ \\
\hline$F$ & $(\mathrm{mg} / \mathrm{kg})$ & $<550$ & 653 & $<550$ & 804 & $<550$ & 593 & 667 & $<550$ & $<550$ & $<550$ & $<550$ & 568 \\
\hline $\mathrm{S}$ & $(\mathrm{mg} / \mathrm{kg})$ & $<300$ & $<300$ & 319 & 336 & 326 & 323 & 359 & 330 & $<300$ & $<300$ & $<300$ & $<300$ \\
\hline
\end{tabular}


Tabela 4. (continuação)

\begin{tabular}{|c|c|c|c|c|c|c|c|c|c|c|c|c|c|c|}
\hline \multicolumn{2}{|c|}{ Amostra } & $\begin{array}{c}\text { PL18- } \\
20\end{array}$ & $\begin{array}{c}\text { PL44- } \\
46\end{array}$ & $\begin{array}{c}\text { PL48- } \\
50\end{array}$ & $\begin{array}{c}\text { PL54- } \\
56\end{array}$ & \multicolumn{2}{|c|}{ PL60-64 } & \multirow{2}{*}{$\begin{array}{c}\text { PL88- } \\
90 \\
08 / 106\end{array}$} & \multirow{2}{*}{$\begin{array}{c}\text { PPE1- } \\
42 \mathrm{~m} \\
08 / 107\end{array}$} & \multirow{2}{*}{$\begin{array}{c}\text { PPE1- } \\
74 \mathrm{~m} \\
08 / 108\end{array}$} & \multirow{2}{*}{$\begin{array}{l}\text { PPE1- } \\
84 \mathrm{~m} \\
08 / 109\end{array}$} & \multicolumn{2}{|c|}{ PPE1-94m } & \multirow[t]{2}{*}{ LD } \\
\hline Núme & o Lab. & $08 / 101$ & $08 / 102$ & $08 / 103$ & $08 / 104$ & $08 / 105 a$ & $08 / 105 b$ & & & & & $08 / 110 a$ & 08/110b & \\
\hline $\mathrm{SiO} 2$ & $(\%)$ & 52,67 & 49,95 & 49,62 & 54,07 & 51,09 & 50,80 & 52,21 & 50,49 & 52,23 & 51,13 & 51,16 & 50,99 & 0,03 \\
\hline $\mathrm{Al} 2 \mathrm{O} 3$ & $(\%)$ & 12,34 & 12,69 & 12,67 & 10,91 & 12,89 & 12,82 & 12,76 & 12,77 & 12,50 & 12,35 & 12,82 & 12,81 & 0,01 \\
\hline $\mathrm{MnO}$ & $(\%)$ & 0,184 & 0,230 & 0,223 & 0,237 & 0,209 & 0,211 & 0,186 & 0,246 & 0,187 & 0,189 & 0,167 & 0,168 & 0,002 \\
\hline $\mathrm{MgO}$ & $(\%)$ & 3,75 & 4,42 & 4,42 & 3,75 & 4,18 & 4,10 & 4,04 & 4,45 & 4,24 & 4,22 & 3,78 & 3,77 & 0,01 \\
\hline $\mathrm{CaO}$ & $(\%)$ & 7,52 & 8,45 & 8,47 & 6,56 & 8,11 & 8,12 & 6,98 & 8,39 & 6,79 & 7,31 & 7,17 & 7,16 & 0,01 \\
\hline $\mathrm{Na} 2 \mathrm{O}$ & $(\%)$ & 2,63 & 2,59 & 2,84 & 3,18 & 2,88 & 2,94 & 2,70 & 3,08 & 2,80 & 2,91 & 2,81 & 2,75 & 0,02 \\
\hline $\mathrm{K} 2 \mathrm{O}$ & $(\%)$ & 1,90 & 1,50 & 1,46 & 1,77 & 1,65 & 1,65 & 2,03 & 1,52 & 2,04 & 1,67 & 1,66 & 1,65 & 0,01 \\
\hline TiO2 & $(\%)$ & 3,304 & 3,636 & 3,635 & 3,307 & 3,653 & 3,661 & 3,431 & 3,552 & 3,532 & 3,788 & 3,657 & 3,694 & 0,007 \\
\hline P2O5 & $(\%)$ & 0,422 & 0,432 & 0,438 & 0,442 & 0,509 & 0,503 & 0,488 & 0,437 & 0,498 & 0,473 & 0,510 & 0,505 & 0,003 \\
\hline $\mathrm{Fe} 2 \mathrm{O} 3$ & $(\%)$ & 14,51 & 15,63 & 15,69 & 13,25 & 14,49 & 14,43 & 14,11 & 15,48 & 14,25 & 15,28 & 15,30 & 15,26 & 0,01 \\
\hline Loi & $(\%)$ & 0,34 & 0,20 & 0,20 & 2,62 & 0,79 & 0,79 & 0,66 & 0,08 & 1,04 & 0,72 & 1,01 & 1,09 & 0,01 \\
\hline Total & $(\%)$ & 99,57 & 99,73 & 99,67 & 100,10 & 100,45 & 100,03 & 99,60 & 100,50 & 100,11 & 100,04 & 100,04 & 99,85 & \\
\hline $\mathrm{Ba}$ & $(\mathrm{mg} / \mathrm{kg})$ & 491 & 448 & 421 & 509 & 497 & 490 & 499 & 439 & 486 & 434 & 470 & 463 & 37 \\
\hline $\mathrm{Ce}$ & $(\mathrm{mg} / \mathrm{kg})$ & 112 & 84 & 129 & 109 & 96 & 87 & 106 & 118 & 107 & 97 & 100 & 74 & 35 \\
\hline Co & $(\mathrm{mg} / \mathrm{kg})$ & 33 & 37 & 39 & 32 & 31 & 32 & 31 & 39 & 29 & 31 & 31 & 30 & 6 \\
\hline $\mathrm{Cr}$ & $(\mathrm{mg} / \mathrm{kg})$ & $<13$ & $<13$ & 13 & 16 & $<13$ & $<13$ & 13 & 15 & $<13$ & $<13$ & $<13$ & $<13$ & 13 \\
\hline $\mathrm{Cu}$ & $(\mathrm{mg} / \mathrm{kg})$ & 187 & 116 & 121 & 143 & 65 & 66 & 55 & 129 & 70 & 65 & 65 & 65 & 5 \\
\hline $\mathrm{Ga}$ & $(\mathrm{mg} / \mathrm{kg})$ & 24 & 23 & 24 & 17 & 25 & 25 & 25 & 23 & 25 & 25 & 25 & 25 & 9 \\
\hline $\mathrm{La}$ & $(\mathrm{mg} / \mathrm{kg})$ & 46 & 34 & 35 & 34 & 39 & 32 & 31 & 44 & 30 & 43 & 41 & 51 & 28 \\
\hline $\mathrm{Nb}$ & $(\mathrm{mg} / \mathrm{kg})$ & 23 & 21 & 21 & 20 & 22 & 22 & 23 & 22 & 23 & 24 & 22 & 22 & 9 \\
\hline $\mathrm{Nd}$ & $(\mathrm{mg} / \mathrm{kg})$ & 71 & 59 & 62 & 44 & 74 & 77 & 54 & 61 & 60 & 72 & 65 & 78 & 14 \\
\hline $\mathrm{Ni}$ & $(\mathrm{mg} / \mathrm{kg})$ & 25 & 25 & 26 & 25 & 22 & 22 & 21 & 27 & 23 & 23 & 22 & 21 & 5 \\
\hline $\mathrm{Pb}$ & $(\mathrm{mg} / \mathrm{kg})$ & 17 & 16 & 15 & 16 & 19 & 18 & 17 & 16 & 15 & 16 & 14 & 13 & 4 \\
\hline $\mathrm{Rb}$ & $(\mathrm{mg} / \mathrm{kg})$ & 39 & 29 & 28 & 29 & 25 & 25 & 40 & 30 & 44 & 34 & 36 & 36 & 3 \\
\hline Sc & $(\mathrm{mg} / \mathrm{kg})$ & 29 & 31 & 32 & 29 & 30 & 31 & 31 & 32 & 29 & 32 & 31 & 31 & 14 \\
\hline $\mathrm{Sr}$ & $(\mathrm{mg} / \mathrm{kg})$ & 459 & 479 & 488 & 583 & 487 & 489 & 420 & 482 & 386 & 421 & 460 & 464 & 2 \\
\hline Th & $(\mathrm{mg} / \mathrm{kg})$ & 14 & 13 & 12 & 12 & 13 & 14 & 14 & 13 & 12 & 14 & 13 & 13 & 7 \\
\hline U & $(\mathrm{mg} / \mathrm{kg})$ & 8 & 8 & 8 & 7 & 7 & 6 & 6 & 6 & 7 & 6 & 7 & 6 & 3 \\
\hline V & $(\mathrm{mg} / \mathrm{kg})$ & 407 & 492 & 445 & 362 & 412 & 420 & 370 & 445 & 385 & 431 & 413 & 415 & 9 \\
\hline$Y$ & $(\mathrm{mg} / \mathrm{kg})$ & 37 & 34 & 34 & 34 & 38 & 38 & 39 & 36 & 39 & 38 & 38 & 39 & 2 \\
\hline $\mathrm{Zn}$ & $(\mathrm{mg} / \mathrm{kg})$ & 127 & 129 & 130 & 118 & 132 & 130 & 130 & 127 & 131 & 131 & 133 & 133 & 2 \\
\hline $\mathrm{Zr}$ & $(\mathrm{mg} / \mathrm{kg})$ & 279 & 254 & 249 & 261 & 267 & 267 & 292 & 258 & 292 & 284 & 269 & 274 & 2 \\
\hline $\mathrm{Cl}$ & $(\mathrm{mg} / \mathrm{kg})$ & $<50$ & $<50$ & $<50$ & $<50$ & $<50$ & $<50$ & $<50$ & $<50$ & $<50$ & $<50$ & $<50$ & $<50$ & 50 \\
\hline$F$ & $(\mathrm{mg} / \mathrm{kg})$ & $<550$ & $<550$ & $<550$ & 2354 & 644 & $<550$ & 554 & $<550$ & 1018 & 562 & $<550$ & 744 & 550 \\
\hline$S$ & $(\mathrm{mg} / \mathrm{kg})$ & $<300$ & $<300$ & $<300$ & $<300$ & $<300$ & $<300$ & $<300$ & $<300$ & $<300$ & $<300$ & $<300$ & $<300$ & 300 \\
\hline
\end{tabular}

Tabela 5. Classificação dos basaltos da área de estudo baseada em Peate, Hawkesworth e Mantovani (1992). Estes autores (na sua tabela 2) utilizam 12 parâmetros químicos e aqui são apresentados apenas 9, uma vez que três deles (SiO2, $\mathrm{Ti} / \mathrm{Zr}$ e Ti/Y) não foram relevantes para diferenciar os basaltos de Bonfim Paulista. A classe final para cada um os basaltos B1, B2 e B3 é apresentada na última linha da tabela. Classes de basaltos de alto Ti de acordo com Peate, Hawkesworth e Mantovani (1992): $\mathbf{U}=$ Urubici, $\mathbf{P i}=$ Pitanga, $\mathbf{P a}=$ Paranapanema.

\begin{tabular}{|c|c|c|c|c|c|c|}
\hline \multirow{2}{*}{ Parâmetro } & \multicolumn{2}{|c|}{ Bas alto $1-\mathrm{B} 1$} & \multicolumn{2}{|c|}{ Bas alto 2 - B2 } & \multicolumn{2}{|c|}{ Bas alto 3 - B3 } \\
\hline & Valor & Class ificação & Valor & Clas sificação & Valor & Class ificação \\
\hline $\mathrm{TiO} 2$ & $3,4-3,8$ & $\mathrm{U}-\mathrm{Pi}$ & $3,3-3,6$ & $\mathrm{U}-\mathrm{Pi}$ & $3,8-3,9$ & $\mathrm{U}-\mathrm{Pi}$ \\
\hline $\mathrm{P} 2 \mathrm{O} 5$ & $0,47-0,51$ & $U-\mathrm{Pi}$ & $0,42-0,44$ & $\mathrm{Pi}-\mathrm{Pa}$ & $0,63-0,64$ & U-Pi-Pa \\
\hline $\mathrm{Fe} 2 \mathrm{O} 3$ & $14,1-15,3$ & $\mathrm{Pi}-\mathrm{Pa}$ & $14,5-15,7$ & $\mathrm{Pi}-\mathrm{Pa}$ & $15,5-15,7$ & $\mathrm{Pi}-\mathrm{Pa}$ \\
\hline $\mathrm{Sr}$ & $386-489$ & $\mathrm{Pi}$ & $459-488$ & $\mathrm{Pi}$ & $491-505$ & $\mathrm{Pi}$ \\
\hline $\mathrm{Ba}$ & $434-499$ & $\mathrm{Pi}-\mathrm{Pa}$ & $421-500$ & $\mathrm{Pi}-\mathrm{Pa}$ & $509-542$ & U-Pi-Pa \\
\hline $\mathrm{Zr}$ & $267-292$ & $U-P i$ & $249-286$ & $\mathrm{Pi}$ & $301-305$ & $U-P i-P a$ \\
\hline $\mathrm{Zr} / \mathrm{Y}$ & $7-7,5$ & $U-\mathrm{Pi}$ & $7,2-7,7$ & $\mathrm{U}-\mathrm{Pi}$ & $7,4-7,5$ & $\mathrm{U}-\mathrm{Pi}$ \\
\hline $\mathrm{Sr} / \mathrm{Y}$ & $10,3-12,6$ & $\mathrm{Pi}-\mathrm{Pa}$ & $13-13,7$ & $\mathrm{Pi}-\mathrm{Pa}$ & $12,1-12,3$ & $\mathrm{Pi}-\mathrm{Pa}$ \\
\hline $\mathrm{Ba} / \mathrm{Y}$ & $11,6-12,8$ & $\mathrm{Pi}-\mathrm{Pa}$ & $12,4-13,5$ & $\mathrm{Pi}-\mathrm{Pa}$ & $12,7-13,2$ & $\mathrm{Pi}-\mathrm{Pa}$ \\
\hline Final & \multicolumn{2}{|c|}{ Pitanga } & \multicolumn{2}{|c|}{ Pitanga } & \multicolumn{2}{|c|}{ Pitanga } \\
\hline
\end{tabular}



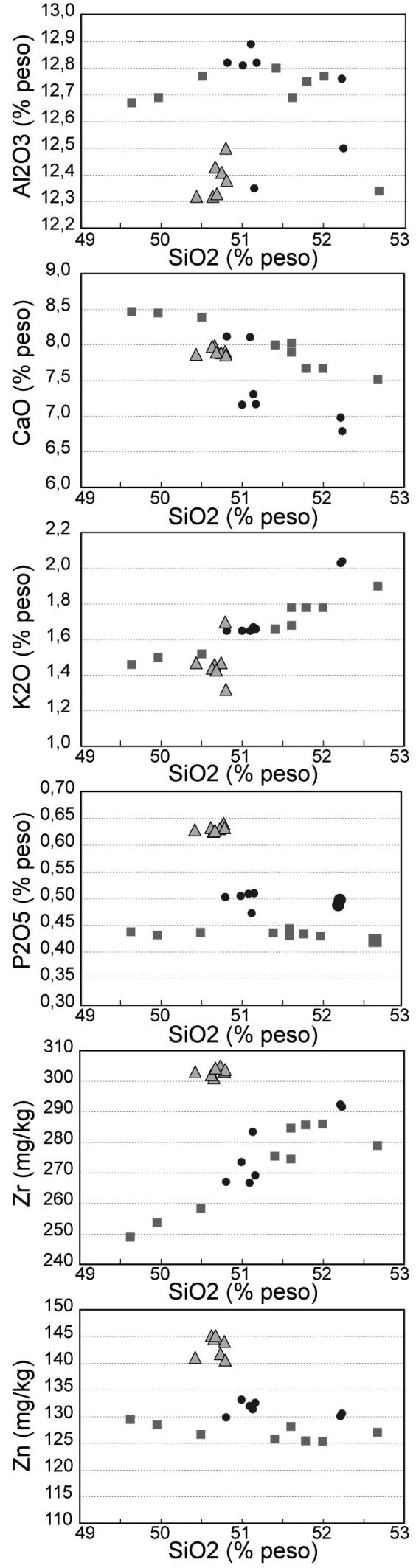

- Basalto 1
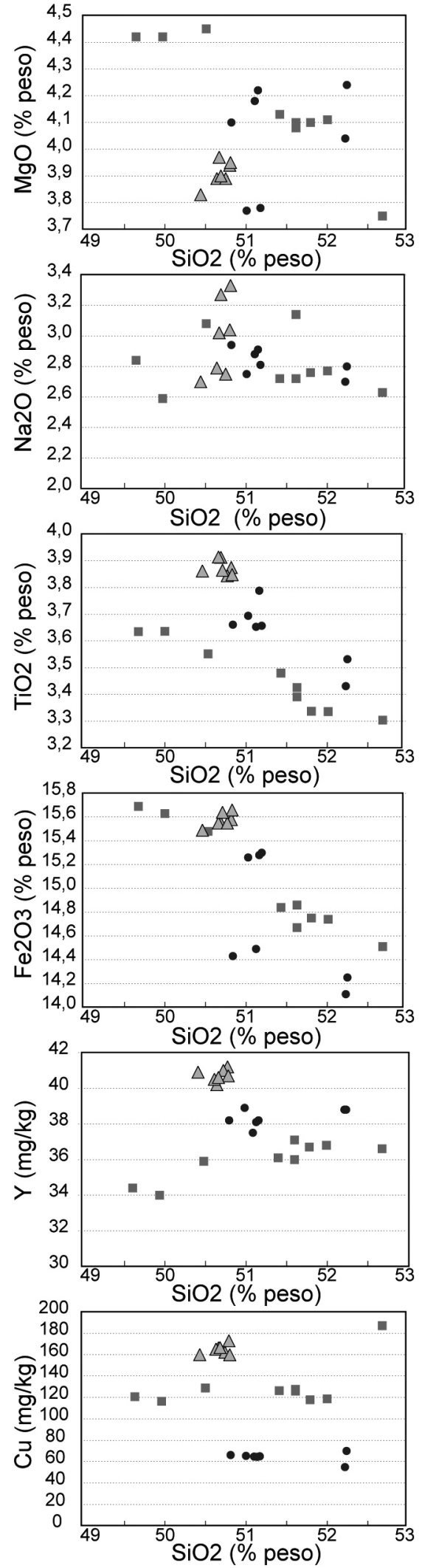

Basalto $2 \triangle$ Basalto 3
Figura 10. Diagramas de variação para alguns óxidos maiores e elementos menores usando $\mathrm{SiO} 2$ como um índice de variação para os basaltos de Bonfim Paulista. 

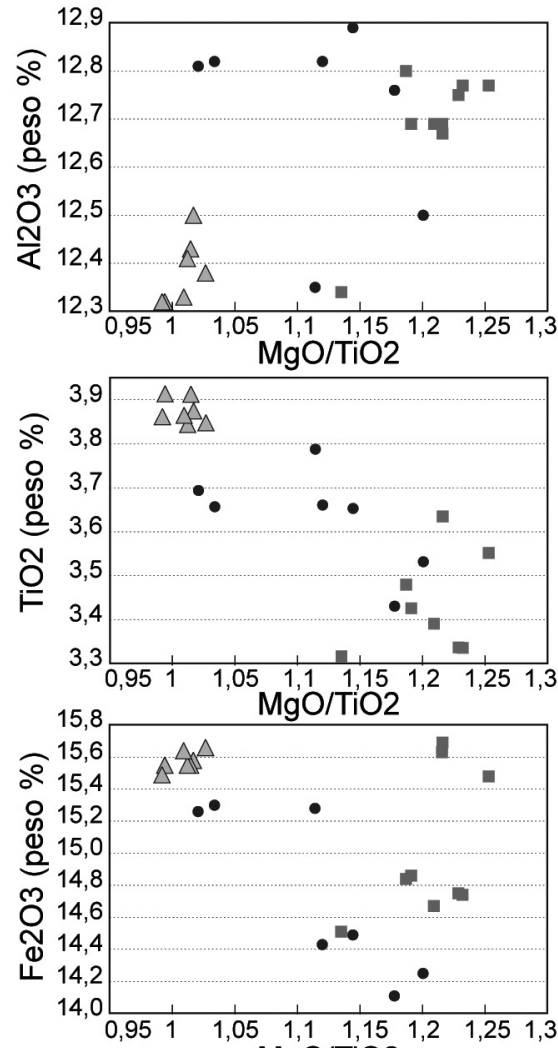

$\mathrm{MgO} / \mathrm{TiO} 2$
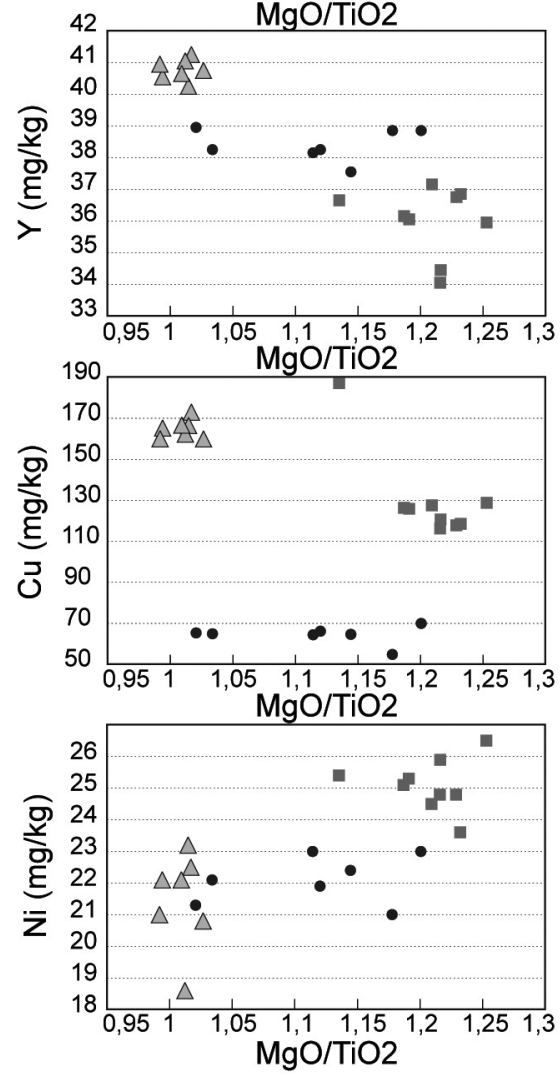

- Basalto 1 - Basalto $2 \triangle$ Basalto 3
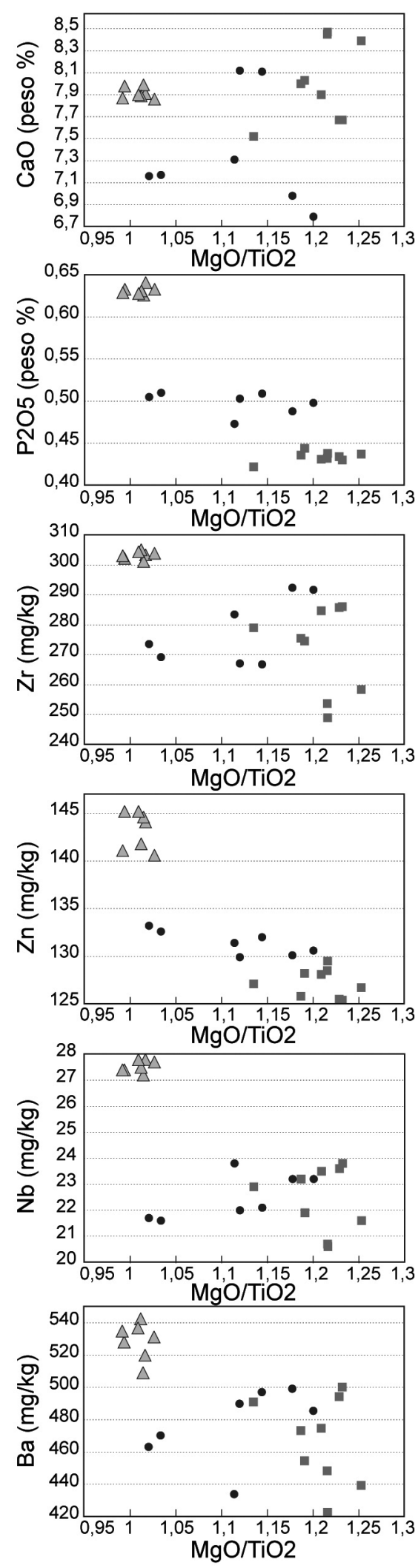

Figura 11. Diagramas de variação para alguns óxidos maiores e elementos menores usando $\mathrm{MgO} / \mathrm{TiO} 2$ como um índice de variação para os basaltos de Bonfim Paulista. 


\section{CONCLUSÕES}

A Formação Serra Geral, na região de Ribeirão Preto, apresenta espessuras que oscilam entre $40 \mathrm{~m}$, ao longo de algumas drenagens, até 170 a $240 \mathrm{~m}$, em topos de colinas. As variações acentuadas das cotas de contato entre arenitos da Formação Botucatu e basaltos, observadas em poços muito próximos entre si, são atribuídas à preservação do relevo de dunas devido à colocação passiva dos derrames de lava. As cotas do contato basalto/arenito variam até $160 \mathrm{~m}$, sendo que a porção mais baixa, com alongamento predominante segundo a direção NE-SW, coincide com a área urbana de Ribeirão Preto. A extensão lateral mínima dos derrames, com base nos dados de afloramentos, é de cerca de $30 \mathrm{~km}$. No entanto, as espessuras identificadas e os mecanismos de colocação, a exemplo do que é apresentado na literatura, permitem classificar os basaltos de Ribeirão como sheet-like lobes, sendo de se esperar que as suas extensões laterais sejam muito grandes, possivelmente da ordem de $600 \mathrm{~km}$ ou mais, a exemplo do que ocorre no Columbia River Basalt Group e outras províncias basálticas.

Os trabalhos realizados na região de Ribeirão Preto permitiram estabelecer a estratigrafia dos derrames de basalto, principalmente no distrito de Bonfim Paulista, onde foram realizados trabalhos de detalhe, e elaborar mapa geológico compatível com a escala 1:25.000. A morfologia em degraus, típica de áreas basálticas, foi extremamente útil para o mapeamento dos contatos entre os derrames. A estratigrafia obtida de dados de poços e de afloramentos foi corroborada pelas características geoquímicas das amostras coletadas. Foram identificados, da base para o topo, quatro derrames, denominados pelas siglas B1, B2, B3 e B4. A extrapolação desta estratigrafia para a região circunvizinha a Bonfim Paulista ainda é bastante limitada, devido aos desnivelamentos dos contatos, mas pode ser feita na direção de Serrana, passando por Cravinhos. A geoquímica constitui uma ferramenta promissora para que a extrapolação atinja uma região maior. Além da estratigrafia, as feições de geologia física, observadas em campo, permitiram identificar uma série de processos relativos tanto à colocação como às historias de resfriamento de cada basalto.

B1 apresenta várias feições que indicam que o mecanismo de inflação foi importante para a sua colocação. As evidências da atuação deste fenômeno são: zona vesicular superior muito espessa ou mesmo duas zonas vesiculares; vesículas e geodos tipicamente alongados na horizontal, com base inferior planar e topos irregulares, mostrando a presença de crosta superior solidificada; veios de maior cristalinidade ou porções mais vesiculadas, ambos derivados de cristalização de líquidos residuais (residuum).
Fenocristais milimétricos de piroxênio são característicos de B2. Na porção superior deste podem ocorrer dois níveis vesiculares; arenitos intertrappe pouco espessos e descontínuos, além de brechas (fragmentos de B2-VA em matriz de arenito) ocorrem no contato com B3.

B3 é perfeitamente distinguível dos outros basaltos por apresentar porção basal colunada (B3-C) e superior de entablamento (B3-E) e ser muito mais espesso. Também são características específicas de B3: fraturas sub-horizontais de grande extensão, tanto entre B2 e B3, como entre B3-C e B3-E, originadas hidraulicamente (elevada pressão de fluidos) e acompanhadas por brechas hidráulicas; e bolsões métricos a decamétricos de brechas hidráulicas na porção colunada, evidenciando acúmulo heterogêneo de fluidos em porções basais de B3. De acordo com a literatura, a presença de entablamento indica resfriamento extremamente rápido, o que requer o mecanismo de correntes de convecção de água, possivelmente oriunda de inundações, sugerindo grande disponibilidade de água no ambiente, pelo menos em determinado período de tempo. Sugere-se, com base no diâmetro das colunas do entablamento e estimativas das taxas de resfriamento oriundas da literatura, que B3 tenha se solidificado em um período de tempo da ordem de 2 anos. Entablamento é descrito em outras regiões do Estado de São Paulo e também no Paraná, sugerindo que basaltos muito espessos, e provavelmente com extensões de centenas de quilômetros, não são raros na Bacia do Paraná.

Entablamento que ocorre em camada, no contato entre B3-E e B3-C, e caracterizado por fraturamento denso de baixo ângulo e veios sub-horizontais, sugere, de acordo com a literatura, a atuação de fraturas de inflação.

Os basaltos B1, B2 e B3 são de alto Ti e compatíveis com o tipo Pitanga. A estratigrafia estabelecida com base em dados de afloramentos e dos poços perfurados foi confirmada pelas análises químicas, sendo que B3 é perfeitamente distinguível de $\mathrm{B} 2$ e $\mathrm{B} 1$ com relação a vários óxidos $\left(\mathrm{Al}_{2} \mathrm{O}_{3}, \mathrm{P}_{2} \mathrm{O}_{5}, \mathrm{TiO}_{2}\right.$ e $\left.\mathrm{MgO}\right)$ e elementos traço ( $\mathrm{Ni}, \mathrm{Zn}, \mathrm{Cu}$, $\mathrm{Y})$. A distinção entre $\mathrm{B} 1$ e $\mathrm{B} 2$ existe mas não é tão evidente. Em B2 as concentrações de $\mathrm{SiO}_{2}$ aumentam conforme diminui a profundidade das amostras no derrame, evidenciando que processos de diferenciação magmática devem ter atuado durante a cristalização deste basalto.

\section{AGRADECIMENTOS}

Este trabalho foi financiado pela FAPESP, na forma de um projeto de auxílio à pesquisa (processo número 04/11798-4, projeto FRATASG coordenado pela Dra. Amélia João Fernandes), de uma bolsa de doutorado (processo número 04/15543-0, doutorando Ingo Wahnfried) e de uma bolsa de iniciação científica (processo número 
2005/00101-5, aluno de graduação Carlos Henrique Maldaner). A coordenação do projeto esteve a cargo do Instituto Geológico - SMASP e o apoio de infra-estrutura, a cargo do Laboratório de Modelos Físicos (LAMO) - IGc/ USP e do Instituto Geológico - SMASP. Agradecimentos são estendidos ao Professor Dr. Valdecir Janasi do Instituto de Geociências da USP, pelas discussões acerca da geoquímica dos basaltos, e a todos os componentes da equipe do projeto FRATASG, pelo acompanhamento nos trabalhos de campo.

\section{REFERÊNCIAS BIBLIOGRÁFICAS}

ALMEIDA, F. F. M. Botucatu, um deserto triássico da América do Sul. Notas Preliminares e Estudos da Divisão de Geologia e Mineralogia do DNPM, v. 86, p. 1-21, 1954.

ALMEIDA F. F. M. Distribuição regional e relações tectônicas do magmatismo pós-paleozóico no Brasil. Revista Brasileira de Geociências, v. 16, n. 4, p. 325-349, 1986.

ASSINE, M. L.; PIRANHA, J. M.; CARNEIRO, C. D. R. Os paleodesertos Pirambóia e Botucatu. In: MANTESSO NETO, V.; BARTORELLI, A.; CARNEIRO, A. D. R.; BRITO-NEVES, B. B.(Ed.) Geologia do Continente SulAmericano: evolução da obra de Fernando Flávio Marques de Almeida. São Paulo: Beca, 2004. .p. 245-264.

BJORNBERG, A. J. S. ; KUTNER, A. S. Resumo das feições geológicas de interesse às fundações em rocha, em barragens da Bacia do Alto Paraná. In: SIMPÓSIO SOBRE A GEOTECNIA DA BACIA DO ALTO PARANÁ, 1983., São Paulo. Anais... São Paulo: ABMS/ABGE/ CBMR, 1983 . v. 1A, p. 263-297.

BJORNBERG, A .J. S. Sedimentos pós-cretácicos do leste do Estado de São Paulo. 1965. 133 f. Tese (Livre-Docência) - Escola de Engenharia de São Carlos, Universidade de São Paulo, São Carlos, 1965.

BUDKEWITSCH, P.; ROBIN, P. Y. Modelling the evolution of columnar joints. Journal of Volcanology and Geothermal Research, v. 59, n. 33, p. 219-239, 1994.

CORDANI, U. G.; VANDOROS, P. Basaltic rocks of the Paraná Basin. In: BIGARELLA, J. J.; BECKER, R. D.; PINTO, I. D. (Ed.) Problems in Brazilian Gondwana Geology. Curitiba: DG-UFPR, 1967. p. 207-234.

FERNANDES, L. A.; COIMBRA, A. M. Revisão estratigráfica da parte oriental da Bacia Bauru. Revista Brasileira de Geociências, v. 30, n. 4, p. 717-728, 2000.
FERNANDES, A. J.; ROULEAU, A.; MALDANER, C. H. Métodos e resultados de levantamento e de análise das fraturas nos basaltos de Ribeirão Preto, SP: aplicação à elaboração de modelo hidrogeológico conceitual (em preparação).

GOMES, R. L. G.; RODRIGUES, J. E. Reconhecimento dos diferentes tipos de derrames basálticos segundo a compartimentação entablamento-colunata em algumas pedreiras do Estado de São Paulo. In: CONGRESSO BRASILEIRO DE GEOLOGIA DE ENGENHARIA, 9., 1999. São Pedro. Panorama da Geologia de Engenharia... São Paulo: ABGE, 1999. 1 CD-ROM.

JANASI, V. A.; NEGRI, F. A.; MONTANHEIRO, T. J.; FREITAS, V. A.; ROCHA, B. C.; REIS, P. M. Geochemistry of the eocretacic basalt magmatism in the Piraju-Ourinhos region, SE Brazil, and implications to the stratigraphy of the Serra Geral Formation. Revista Brasileira de Geociências, n. 37, n. 1, p. 148-162, 2007.

JERRAM, D.; MOUNTNEY, N.; HOLZFORSTER, F.; STOLLHOFEN, H. Internal stratigraphic relationships in the Etendeka Group in the Huab Basin, NW Namibia: understanding the onset of the flood volcanism. Journal of Geodynamics, v. 28, p. 393-418, 1999.

JERRAM, D.; MOUNTNEY, N.; HOWELL, J. A.; LONG, D.; STOLLHOFEN, H. Death of a sand sea: an active aeolian erg systematically buried by the Etendeka flood basalts of NW Namibia. Journal of the Geological Society, v. 157, p. 513-516, 2000.

JERRAM, D.; STOLLHOFEN, H. Lava-sediment interaction in the desert settings; are all peperite-like textures the result of magma-water interaction? Journal of Volcanology and Geothermal Research, v. 114, p. 231-249, 2002.

KATTENHORN, A. S.; SCHAEFER, C. J. Thermalmechanical modeling of cooling history and fracture development in inflationary basalt lava flows. Journal of Volcanology and Geothermal Research, v. 170, p. 181-197, 2008.

LE BAS, M. J.; LE MAITRE, R. W.; STRECKEISEN, A.; ZANETTIN, B. A. Chemical classification of volcanic rocks based on the total alkali-silica diagram. Journal of Petrology, v. 27, n. 3, p. 745-750, 1986.

LEINZ, V. Contribuição à geologia dos derrames basálticos do sul do Brasil. Boletim FFCHL-USP. Geologia, v. 103 , n. 5, p. 1-103, 1949. 
LEINZ, V.; BARTORELLI, A.; SADOWSKI, G. R.; ISOTTA, C. A. L. Sobre o comportamento espacial do Trapp basáltico da Bacia do Paraná. Boletim da $S B G$, v. 15 , n. 4, p. 79-91, 1966.

LONG, P. E.; WOOD, B. J. Structures, textures, and cooling histories of Columbia River basalt flows. Geological Society of America, v. 97, n. 9, p. 1144-1155, 1986.

MACHADO, F. B.; NARDY, A. J. R.; SQUISATO, E.; OLIVEIRA, M. A. F. O vulcanismo Serra Geral na porção NE da Bacia do Paraná: aspectos petrográficos e geoquímicos. In: SIMPÓSIO DE VULCANISMO E AMBIENTES ASSOCIADOS, 3., 2005. Cabo Frio. Anais... Rio de Janeiro: SBG, 2005, v. 1, p. 243-248.

MACHADO, F. B.; NARDY, A. J. R.; OLIVEIRA, M. A. F. Geologia e aspectos petrológicos das rochas intrusivas e efusivas mesozoicas de parte da borda leste da Bacia do Paraná no Estado de São Paulo. Revista Brasileira de Geociências, v. 37, n. 1, p. 64-80, 2007.

MARQUES FILHO, P. L.; CORREIA, P. C.; LEVIS, P.; ANDRADE, C. A. V. Características usuais e aspectos peculiares do manto de alteração e transição solo-rocha em basaltos. In: CONGRESSO BRASILEIRO DE GEOLOGIA DE ENGENHARIA, 3., 1981. Itapema. Anais... São Paulo: ABGE, 1981. v. 12, p. 53-72.

MARQUES, L. S.; ERNESTO, M. O magmatismo toleítico da Bacia do Paraná. In: MANTESSO NETO, V.; BARTORELLI, A.; CARNEIRO, A. D. R.; BRITO-NEVES, B. B. (Ed.). Geologia do Continente Sul-Americano: evolução da obra de Fernando Flávio Marques de Almeida. São Paulo: Beca, 2004. p. 245-264.

MASSOLI, M. Caracterização litofaciológica das formações Pirambóia e Botucatu em subsuperficie, no município de Ribeirão Preto (SP), e sua aplicação na prospecção de águas subterrâneas. 2007. 1 v. Tese (Doutorado) - Instituto de Geociências e Ciências Exatas, Universidade Estadual Paulista, Rio Claro, 2007.

MELFI, A. J.; PICCIRILLO, E. M.; NARDY, A. J. Geological and magmatic aspects of the Paraná Basin: an introduction. In: PICCIRILLO, E. M.; MELFI, A. J. (Ed.). The Mesozoic Foold Volcanism PF the Paraná Basin: petrogenetic and geophysical aspects. São Paulo: IAGUSP, p. 1-13, 1988.

MELO, M. S. A Formação Rio Claro e depósitos associados: sedimentação neocenozóica na Depressão Periférica
Paulista. 1995. 144 f. Tese (Doutorado) - Instituto de Geociências, Universidade de São Paulo, São Paulo, 1995.

MILANI, E. J. Comentários sobre a origem e evolução tectônica da Bacia do Paraná. In: MANTESSO NETO, V.; BARTORELLI, A.; CARNEIRO, A. D. R.; BRITO-NEVES, B. B. (Ed.) Geologia do Continente Sul-Americano: evolução da obra de Fernando Flávio Marques de Almeida. São Paulo: Beca, 2004. p. 265-279.

MINEROPAR/CPRM. Geologia e recursos minerais do sudoeste do Estado do Paraná. Programa Geologia do Brasil, Levantamentos Geológicos Básicos, Curitiba,: CPRM, 2006. 94 p. Escala: 1:200.000.

MORI, P. E.; REEVES, S.; CORREIA, C. T.; HAUKKA, M. Development of a fused glass disc XRF facility and comparison with the pressed powder pellet technique at Instituto de Geociências, Universidade de São Paulo. Revista Brasileira de Geociências, v. 29, p. 441-446, 1999.

NARDY, A. J. R.; OLIVEIRA, M. A. F.; BETANCOURT, R. H. S.; VERDUGO, D. R. H.; MACHADO, F. B. Geologia e estratigrafia da Formação Serra geral. Geociências, v. 21, n. 1-2, p. 13-30, 2002.

NARDY, A. J. R.; SQUISATO, E.; MACHADO, F. B.; OLIVEIRA, M. A. F. Os derrames básicos da borda leste da Bacia do Paraná no Estado de São Paulo: considerações preliminares. In: SIMPÓSIO DE VULCANISMO E AMBIENTES ASSOCIADOS, 3., 2005. Cabo Frio. Anais... São Paulo: SBG, 2005, v. 1, p. 249-254.

NARDY, A. J. R.; MACHADO, F .B.; OLIVEIRA, M. A. F. As rochas vulcânicas mesozoicas ácidas da Bacia do Paraná: litoestratigrafia e considerações geoquímico-estratigráficas. Revista Brasileira de Geociências, v. 38, n. 1, p. 178-195, 2008.

NEGRI, F. A.; JANASI, V. A.; MONTANHEIRO, T. J. Derrames basálticos da Formação Serra Geral na região entre Piraju e Assis (SP): o uso da geoquímica como ferramenta estratigráfica. In: SIMPÓSIO DE VULCANISMO E AMBIENTES ASSOCIADOS, 4., 2008. Foz do Iguaçu. Anais... Cascavel, PR: Coluna do Saber, 2008. 1 CD-ROM.

PEATE,D.W.;HAWKESWORTH,C.J.;MANTOVANI, M. S. M. Chemical stratigraphy of the Paraná lavas, South America: classification of magma types and their spatial distribution. Bulletin of Volcanology, v. 55, p. 119-139, 1992. 
PICIRILLO, E. M.; RAPOSO, M. I. B.; MELFI, A. J.; COMIN-CHIARAMONTI, P.; CORDANI, U.; KAWASHITA, K. Bimodal fissural volcanic suites from the Paraná Basin (Brazil): K-Ar ages, Sr-isotopes and geochemistry. Geochimica Brasiliensis, v. 1, n. 1, p. 55-69, 1987.

PICIRILLO, E. M.; COMIN-CHIARAMONTI, P.; MELFI, A. J.; STOLFA, D.; BELLIENI, G.; MARQUES, L. S.; GIARETTA, A.; NARDY, A. J. R.; PINESE, J. P. P.; RAPOSO, M. I. B.; ROISENBERG, A. Petrochemistry of continentalflood basalt-rhyolite suítes and related intrusives from the Paraná Basin (Brazil). In: PICCIRILLO, E. M.; MELFI, A. J. (Ed.). The Mesozoic Foold Volcanism PF the Paraná Basin: petrogenetic and geophysical aspects. São Paulo: IAG-USP, 1988. p. 1-13.

SÃO PAULO. Secretaria do Meio Ambiente do Estado de São Paulo. Projeto "Sistema de Informação para o Gerenciamento Ambiental do Recurso Hídrico Subterrâneo no Afloramento do Aquífero Guarani no Estado de São Paulo". Cooperação Técnica entre a Secretaria do Meio Ambiente do Estado de São Paulo (Brasil) e a Secretaria de Meio Ambiente, Saúde Pública e Proteção ao Consumidor do Estado da Baviera (Alemanha). 2004. Relatório Técnico. 1 CD-ROM.

SCHERER, C. M. S. Preservation of aeolian genetic units by lava flows in the Lower Cretaceous of the Paraná Basin, southern Brazil. Sedimentology, v. 49, p. 97-116, 2002.

SELF, S. How do continental flood basalt lava flows attain their great length and size? In: SIMPÓSIO DE VULCANISMO E AMBIENTES ASSOCIADOS, 4, 2008. Foz do Iguaçu. Anais... Cascavel, PR: Coluna do Saber, 2008. 1 CD-ROM

SELF, S.; JAY, A. E.; WIDDOWSON, M.; KESZTHELYI, L. P. Correlation of Deccan and Rajahmundry trap lavas: are these the longest and largest lava flows on Earth? Journal of Volcanology and Geothermal Research, v. 172, p. 3-19, 2008.

SELF, S.; KESZTHELYI, L.; THORDARSON, T. The importance of pahoehoe. Annual Review of Earth and Planetary Sciences, v. 26, p. 81-110, 1998.

SINELLI, O. Água subterrânea no município de Ribeirão Preto. In: CONGRESSO BRASILEIRO DE GEOLOGIA, 25., 1971, São Paulo. Anais... São Paulo: SBG, p. 17-34, 1971a.
SINELLI, O. Considerações gerais sobre a tectônica no município de Ribeirão Preto. In: CONGRESSO BRASILEIRO DE GEOLOGIA, 25., 1971, São Paulo. Anais... São Paulo: SBG, p. 145-151, 1971 b.

SINELLI, O.; SOARES, P. C.; CASTRO, P. R. M.; SOUZA, A. WERNICK, E.; PENALVA, F. Mapa geológico do nordeste do Estado de São Paulo. - Folhas de Serrana, Ribeirão Preto, Cravinhos e Bonfim Paulista. Ribeirão Preto: Convênio CNEC/FFCL/USP, 1973. Escala 1:50.000

SOARES, P. C.; LANDIM, M. P. B.; FÚLFARO, V. J.; SOBREIRO NETO, A. F. Ensaio de caracterização do Cretáceo no Estado de São Paulo. Revista Brasileira de Geociências, v. 10, n. 3, p. 177-185, 1980.

SOARES, P. C.; SINELLI, O.; PENALVA, F.; WERNICK, E.; SOUZA, A.; CASTRO, P. R. M. Geologia do Nordeste do Estado de São Paulo,. In: CONGRESSO BRASIlEIRO DE GEOLOGIA, 27., 1973, Aracaju. Anais... Aracaju: SBG, 1973. v. 1, p. 209-236.

SOUZA JUNIOR, N. N. O "entablamento" em derrames basálticos da Bacia do Paraná: aspectos genéticos e caracterização geotécnica. 1992. 257 f. Tese (Doutorado) - Escola de Engenharia de São Carlos, Universidade de São Paulo, São Carlos, 1992.

WAICHEL, B. L.; LIMA, E. F.; LUBACHESKY, R.; SOMMER, C. A. Pahoehoe flows from the central Parana Continental Flood Basalts. Bulletin of Volcanology, v. 68, p. 599-610, 2006. 